NBER WORKING PAPER SERIES

\title{
DOES AID MATTER? \\ MEASURING THE EFFECT OF STUDENT AID \\ ON COLLEGE ATTENDANCE AND COMPLETION
}

\author{
Susan M. Dynarski \\ Working Paper 7422 \\ http://www.nber.org/papers/w7422
NATIONAL BUREAU OF ECONOMIC RESEARCH 1050 Massachusetts Avenue
Cambridge, MA 02138
November 1999

I thank Daron Acemoglu, Courtney Coile, Julie Cullen, Amy Finkelstein, Jeff Kling, Jon Guryan, Jerry Hausman, Sendhil Mullainathan, Steve Pischke, and seminar participants at Harvard, MIT, and NBER for their helpful comments. I especially appreciate the guidance of Josh Angrist, Jon Gruber and Jim Poterba. Support from NBER Pre- and Post- Doctoral Fellowships in Aging and Health is gratefully acknowledged. The views expressed herein are those of the authors and not necessarily those of the National Bureau of Economic Research.

(C) 1999 by Susan M. Dynarski. All rights reserved. Short sections of text, not to exceed two paragraphs, may be quoted without explicit permission provided that full credit, including $(\mathcal{C}$ notice, is given to the source. 
Does Aid Matter? Measuring the Effect of Student Aid on College

Attendance and Completion

Susan M. Dynarski

NBER Working Paper No. 7422

November 1999

JEL No. I22, J24

\begin{abstract}
$\underline{\text { ABSTRACT }}$
Does student aid increase college attendance or simply subsidize costs for infra-marginal students? Settling the question empirically is a challenge, because aid is correlated with many characteristics that influence educational investment decisions. A shift in financial aid policy that affects some youth but not others can provide an identifying source of variation in aid. In 1982, Congress eliminated the Social Security Student Benefit Program, which at its peak provided grants totaling $\$ 3.7$ billiona year to one out of ten college students. Using the death of a parent as a proxy for Social Security beneficiary status, I find that offering $\$ 1,000$ (\$1998) of grant aid increases educational attainment by about 0.16 years and the probability of attending college by four percentage points. The elasticities of attendance and completed years of college with respect to schooling costs are 0.7 to 0.8 . The evidence suggests that aid has a "threshold effect': a student who has crossed the hurdle of college entry with the assistance of aid is more likely to continue schooling later in life than one who has never attempted college. This is consistent with a model in which there are fixed costs of college entry. Finally, a cost-benefit analysis indicates that the aid program examined by this paper was a cost-effective use of government resources.
\end{abstract}

Susan M. Dynarski

Kennedy School of Government

Harvard University

Cambridge, MA 02138

and NBER

susan_dynarski@harvard.edu 


\section{Introduction}

The United States spends billions of dollars each year on financial aid for college students. During the 1998-99 school year, the federal government delivered \$46 billion in grant aid and subsidized loans to students, while colleges and universities spent an additional $\$ 12$ billion. ${ }^{1}$ Policy-makers generally cite their desire to expand access to higher education as their reason for supporting student aid. While stumping for his proposed Hope Scholarship, President Clinton characterized the program as helping to "make at least two years of college as universal at the dawn of the next century as a high school diploma is today."2 However, there is little firm evidence that aid actually serves its policy goal of increasing college attendance. The billions spent annually on aid may simply subsidize students who would have gone to college even in the absence of a subsidy.

Determining whether aid expands access to college is a challenge. The simplest approach is to regress a person's educational attainment against the aid for which he is eligible and interpret the coefficient on aid as its casual effect. But aid is correlated with many characteristics that have their own influence on education, and omitting these variables from the regression produces a biased estimate of the causal effect of aid on education. We can attempt to eliminate this source of bias by controlling for observable characteristics that are correlated with both aid and education. However, if there remain any unobservable characteristics that are correlated with both aid and education then this approach will still fail to capture the causal effect of aid on college attendance.

In order to identify the effect of aid, we need a source of variation in aid that is plausibly exogenous to unobservable attributes that influence college attendance. A discrete shift in aid policy that

\footnotetext{
${ }^{1}$ College Board (1999). Unless otherwise stated, all dollar amounts are in constant 1998 dollars. These figures are for aid delivered directly to students. Indirect aid, in the form of government subsidies to colleges and universities, is also substantial. State governments allocated $\$ 53$ billion for their public universities in academic year 1998-99.

${ }^{2}$ President Clinton in a June 14, 1997, speech at University of California, San Diego.
} 
affects some students but not others is one such source of exogenous variation. In this paper, I analyze the impact on college attendance and completed schooling of a major shift in federal financial aid policy that occurred in the early 1980 s.

From 1965 to 1982, the Social Security Student Benefit Program paid for millions of students to go to college. Under this program, the 18- to 22-year-old children of deceased, disabled or retired Social Security beneficiaries received monthly payments while enrolled full-time in college. Benefits were generous: the average annual payment in 1980 was $\$ 5,400 .{ }^{3}$ During the $1980-81$ school year, the program distributed $\$ 3.7$ billion to college students, while the largest grant program, the Pell Grant, distributed $\$ 4.7$ billion. ${ }^{4}$ At the program's peak, 11 percent of full-time college students aged 18 to 21 were receiving Social Security Student Benefits. ${ }^{5}$

In 1981, Congress voted to eliminate the Social Security Student Benefit Program. Students that were enrolled in college as of May 1982 had their payments severely reduced while those not yet enrolled were ineligible for future subsidies. Program enrollment sank rapidly (see Figure 1). By the 1983-84 academic year, program spending had dropped to $\$ 0.36$ billion (see Figure 2). Except for the introduction of the Pell Grant program in the early 1970s, and the various GI Bills, this is the largest and sharpest change in grant aid for college students that has ever occurred in the United States.

The program's demise provides an opportunity to measure the incentive effects of financial aid. To preview the results, I find that the elimination of the Social Security Student Benefit Program reduced by nearly half the probability that the affected group would go to college. Completed education was reduced by nearly a year. I find that an offer of $\$ 1,000$ in grant aid increases ultimate educational attainment by about 0.16 years and the probability of attending college by about four percentage points

\footnotetext{
${ }^{3}$ Calculated from data in Table 54 in Social Security Administration (1982).

${ }^{4}$ Table A in College Board (1998).

${ }^{5}$ Calculated from data in Table 54 in Social Security Administration (1982) and Table 174 in National Center for Education Statistics (1998).
} 
The elasticities of attendance and years of completed college with respect to schooling costs are estimated to be 0.7 to 0.8 . The evidence suggests that aid has a "threshold effect": a student who has crossed the hurdle of entry with the assistance of aid is more likely to continue schooling later in life than one who has never attempted college. This is consistent with a model in which there are fixed costs of college entry. A cost-benefit analysis indicates that the aid program examined by this paper was a costeffective use of government resources.

The paper is organized as follows. Section II reviews past economic research on the topic and discusses the econometric difficulties of identifying the effect of aid on education. Section III provides background on the Social Security Student Benefit Program and the data set used in the analysis. Section IV discusses the identification strategy. Section $V$ presents results on the effect of aid eligibility on the probability of attending college and average education levels. Section VI discusses the impact of aid on the full distribution of education. Section VII provides some descriptive evidence on how aid affects the type of college students choose to attend. Section VIII analyzes the social welfare implications of the program and Section IX concludes.

\section{Background and Literature Review}

We are interested in the effect of aid on the probability of a person attending and completing college. The theory underlying this relationship is straightforward. In the classic human capital model (Becker, 1993; Griliches, 1977), an individual maximizes his discounted stream of lifetime earnings net of the costs of college:

$$
\operatorname{Max}_{\mathrm{S}_{\mathrm{i}}} \int_{t=0}^{t=S_{i}}-C e^{-r t} d t+\int_{t=S_{i}}^{t=\infty} f\left(S_{i}\right) e^{-r t} d t
$$

In this formulation, the earnings associated with schooling level $S_{i}$ are denoted $f\left(S_{i}\right)$ while $r$ is the cost of borrowing. $C$ denotes tuition costs, assumed constant across the population. 
Maximizing this function over $S_{i}$ yields the following first-order condition:

$$
f\left(S_{i}\right)+C=\frac{f^{\prime}\left(S_{i}\right)}{r}
$$

This is the standard optimal schooling condition, with the addition of the $C$ term. An individual will invest in schooling up to the point that the marginal cost of an additional year of schooling (foregone earnings plus tuition) is equal to its marginal benefit (the discounted stream of earnings attributable to another year of school). Introducing financial aid into the analysis alters this condition only slightly:

$$
f\left(S_{i}\right)+\left(C-A I D_{i}\right)=\frac{f^{\prime}\left(S_{i}\right)}{r}
$$

In this equation, $A I D_{i}$ is the amount of grant aid for which student $i$ is eligible. Intuitively, $C-A I D_{i}$ enters the condition in the same way that $f\left(S_{i}\right)$ because they are both costs of attending college: $C-A I D_{i}$ is the direct cost while $f\left(S_{i}\right)$ is the opportunity cost.

Note that under this simple form of the human capital model government aid for college does not enhance social welfare: aid can only move individuals from the social optimum implied by Equation (2) to the sub-optimal choice of Equation (3). However, there are several conditions under which the optimal schooling choices made by an individual and a social planner might diverge. The first, most widely discussed in the schooling literature, is liquidity constraints. The simplest form of the human capital model assumes that a student can freely borrow while in school. But if students do not have full access to credit markets they will under-invest in education. Under such conditions, grant aid can produce Pareto improvements, though the government could achieve the same end more efficiently by offering loans.

A second reason for government intervention is student uncertainty about the costs and benefits of college. For example, the return to schooling may change over time, due to both aggregate shocks to the market for educated labor and idiosyncratic shocks to the return to a particular degree or specialization. Further, a student may be uncertain about his ability to complete even a year of college (Manski, 1989). If the return to a year of college is uncertain, then even in the absence of liquidity constraints risk-averse individuals will invest in a level of education lower than that implied by Equation (3). If government is less risk-averse than individuals, then a grant toward schooling costs will have positive welfare effects. A 
government loan, in this case, will not have the same positive effect as a grant. Finally, if education produces positive externalities then the private and social optimums will diverge.

The schooling model of Equation (3) implies that individual heterogeneity in schooling choice stems solely from the level of aid a student is offered, as does the following reduced-form equation:

$$
\text { (4) } \quad S_{i}=\alpha_{0}+\beta_{0} A I D_{i}+\varepsilon_{i}
$$

If aid is uncorrelated with other determinants of schooling, then $\beta_{0}$ can be interpreted as the effect of a dollar of aid eligibility on college attendance or completion.

However, we know that aid eligibility is correlated with many characteristics that affect the probability of attending college. For example, the federal government uses need-based aid to encourage the college attendance of poor students. But poor students are less likely to attend college for reasons unrelated to the generosity of aid; this implies that a naive estimate of the effect of aid eligibility will be biased downward, since need-based aid is correlated with variables that decrease college attendance. To take another example, many colleges use merit scholarships to attract high-achieving students. In this case, a naive estimate of the effect of aid eligibility on college attendance will be biased upward. A priori, then, we do not know whether the relationship estimated by Equation (4) over- or under-states the causal effect of aid eligibility on college attendance.

Many studies attempt to overcome this identification problem by estimating:

$$
y_{i}=\alpha_{1}+\beta_{1} A I D_{i}+\gamma_{1} X_{i}+\eta_{i}
$$

where $X_{i}$ is a set of variables correlated with both aid and attendance. Variables typically included in such a regression include family income, test scores, and parental education. Leslie and Brinkman (1988) review more than a dozen studies that estimate some form of Equation (5). Among economists, the most well-known of these studies is College Choice in America, by Charles Manski and David Wise (1983). Manski and Wise develop a multistage model in which students make decisions about college application, quality and attendance, while colleges decide which students to accept and to offer aid. This work focuses on the high school class of 1972, and therefore predates the modern federal aid system. Its out-of-sample estimates predict that $\$ 1,000$ in Pell grant eligibility will increase college attendance by 3.8 percentage 
points. The bulk of the studies that Leslie and Brinkman review are roughly consistent with Manski and Wise, predicting that a $\$ 1,000$ decline in the net price of college will lead to a three to five percentage point increase in the attendance of 18- to 24-year-olds.

However, the approach discussed in the previous paragraph will fail to capture the causal effect of aid offers on attendance if there are any unobservable characteristics that are correlated with both aid and attendance. Examples of variables that affect both aid eligibility and college attendance but are usually unobserved in survey data include academic performance in high school, access to information about college, level of financial assets, and number of siblings in college. Such characteristics can be expressed as a person- or group-specific error term that is correlated with aid:

$$
\begin{aligned}
& y_{i j}=\alpha_{2}+\beta_{2} A I D_{i j}+\gamma_{2} X_{i j}+\mu_{j}+\xi_{i j} \\
& \operatorname{cov}\left(A I D_{i j}, \mu_{j}\right) \neq 0 \\
& \operatorname{cov}\left(A I D_{i j}, \xi_{i j}\right)=0
\end{aligned}
$$

Here, $\mu_{j}$ denotes a group-specific error term. By adding a group-specific effect to the estimating equation, or by taking differences within groups over time, we can eliminate $\mu_{j}$ as a source of bias. The advantage of this approach is that it requires few assumptions about the functional form of factors that influence both aid eligibility and education. ${ }^{6}$

Using such an approach, Kane (1994) exploits cross- and within-state variation in public university tuition to identify the effect of schooling costs on college attendance. His fixed-effects estimates imply that a $\$ 1,000$ decrease in public university tuition prices increases the college attendance of black 18- to 19year olds by 3.7 percentage points. Kane's estimate of the effect of aid eligibility on enrollment, however, is much lower: the impact of Pell grants on college attendance is estimated to be about one-third to one-

\footnotetext{
${ }^{6}$ The key assumption is that the between-group difference in the underlying propensity to attend college is fixed over time.
} 
half of that of an equivalent reduction in tuition. However, as Kane notes, this estimate of the effect of Pell grants is not well identified.

Reyes (1995) analyzes the effect of the 1978 passage and 1981 repeal of the Middle Income Student Assistance Act, which eliminated the income cutoff for the Guaranteed Student Loan (GSL). Reyes finds that $\$ 1,000$ in GSL eligibility raises attendance of young people 0.74 percentage points and years of schooling 0.13 years. During the period that Reyes analyzes, the subsidy value of the guaranteed loan was about half of its face value. If we assume that students full recognize the subsidy value of a loan then the implied effect of a $\$ 1,000$ subsidy is an increase of 0.26 years in schooling and 1.5 percentage points in attendance rates. However, this estimate fails to predict the effect of grant aid if students are debt-averse or do not recognize the subsidy value of loans.

Hansen (1983) and Kane (1995) compare the attendance rates of low- and high-income youth before and after the Pell Grant was introduced in 1973. They find no relative increase in the attendance rate of low-income youth. A review by Leslie and Brinkman (1983) of similar studies of the Pell Grant draws the same conclusion. This failure to detect an effect of the introduction of the Pell Grant program on aggregate enrollment rates is a persistent puzzle in the financial aid literature.

Several authors have examined the impact upon veterans of the passage of the various post-Word War II GI Bills, which like the Social Security Student Benefit Program provided a generous monthly stipend to those in college. Exploiting variation over time in benefit generosity, Angrist (1993) finds that offering educational subsidies to veterans increased their completed schooling by about a year. ${ }^{7}$ Bound and Turner (1999) and Stanley (1999) also conclude that veterans' eligibility for educational benefits increased their completed schooling.

In summary, a large literature examines the effect of aid eligibility on college attendance. Many studies focus on cross-sectional variation in aid and are vulnerable to bias induced by correlation between

\footnotetext{
${ }^{7}$ Angrist estimates the effect of benefits among those who actually take them up; I have converted this to an effect of benefits among those who are eligible, using his estimate of a 57 percent take-up rate.
} 
aid and the unobserved propensity to attend college. A smaller set of studies likely eliminates this source of bias by exploiting variation in aid within groups and over time. Those that examine the introduction of the Pell Grant consistently conclude aid has no effect on the college attendance of youth. By contrast, studies by Kane and Reyes and authors examining the GI Bills find that aid has a positive effect on college attendance. These latter studies, while likely capturing the effect of the programs studied upon the affected populations, do not provide a clear prediction of the effect of grant aid on high school students. The decision-making of veterans likely differs from that of young high school students, since the two populations face different employment options and therefore different opportunity costs of college. And the effect of a subsidy delivered as a low-interest loan or low tuition may well differ from the effect of a subsidy delivered as an outright grant.

\section{The Social Security Student Benefit Program}

In 1965, as part of the legislation that created the Medicare and Medicaid programs, Congress established the Social Security Student Benefit Program. ${ }^{8}$ Prior to 1965, the Social Security Administration stopped paying benefits to the child of a Social Security beneficiary on the child's $18^{\text {th }}$ birthday. With the new legislation, these payments were continued to the $22^{\text {nd }}$ birthday if the child remained unmarried and was enrolled full-time in school. In essence, the new program defined unmarried, full-time students under age 22 as dependents who should receive the same benefits as those paid to children under 18 .

The Social Security Student Benefit Program grew rapidly after its inception. By 1970, more than 400,000 college students aged 18 to 21 were collecting benefits (Figure 1). Program enrollment peaked in 1977 at $700,000 .{ }^{9}$ In1980, one in nine full-time college students aged 18 to 21 was a Social Security student

${ }^{8}$ This section draws on Committee on Ways and Means (1979 and 1982), Luzadis (1983) and Office of the Comptroller General (1979).

${ }^{9}$ Note that some student beneficiaries were enrolled in high school, as child benefits were converted to student benefits if a youth turned 18 while still in high school. A 1973 Social Security Administration analysis of student beneficiaries indicated that 21 percent were enrolled in high school and the balance in post-secondary institutions (Springer, 1976). The figures in the text are for those in post-secondary school only. 
beneficiary. ${ }^{10}$ As Figure 2 shows, spending on the program grew at a similarly rapid pace, from $\$ 2.1$ billion during the 1970-71 academic year 1970 to $\$ 3.7$ billion during 1980-81.

Compared to other student aid programs, the Social Security Student Benefit Program was extremely generous. The average annual benefit in 1980 was $\$ 5,400$. By comparison, the average Pell Grant in the same year was $\$ 1,700$ and the average guaranteed student loan was $\$ 3,800$. A Social Security Student Benefit of $\$ 5,400$ is particularly striking when viewed in the context of educational costs typical of the time: in 1980 , tuition and fees averaged just $\$ 1,600$ at public universities and $\$ 6,100$ at private, four-year colleges (College Board, 1983).

The benefits paid to individual students were not tied to schooling costs or family income. ${ }^{11}$ Instead, the key determinant of the benefit was the earnings history of the parent whose death, disability or retirement triggered Social Security payments to the family. When a claim for benefits was filed, the Social Security Administration reviewed the earnings history of the worker to establish his potential monthly retirement benefit, the Primary Insurance Amount (PIA); PIAs were set highest for those who were consistently employed with high earnings. Each child of a deceased worker was eligible to receive 75 percent of the PIA, while the children of retired and disabled workers were eligible to receive 50 percent. There was a limit to how much a family could receive, however: total family benefits could not exceed 175 percent of the PIA. If the benefits of family members summed to more than 175 percent of the PIA, each one's benefit was reduced by the same percentage until the total was under the family cap. Several months before the $18^{\text {th }}$ birthday of a child beneficiary, the Social Security Administration sent her a letter inquiring into her college plans. A beneficiary who responded that she was already in college, or would be as of her $18^{\text {th }}$ birthday, continued to receive the same benefits she had received as a child. The Social Security Administration asked for verification of enrollment and marital status on an

\footnotetext{
${ }^{10}$ Calculated from data in Table 54 in Social Security Administration (1982) and Table 174 in National Center for Education Statistics (1998).

${ }^{11}$ In this way, the program was quite similar to those versions of the GI Bill in which benefits were paid in a lump sum rather than as a proportion of schooling costs.
} 
annual basis. In the early years of the program, the only verification of college enrollment status was the self-report of the student; in the late 1970s, the Social Security Administration began to require verification from schools. Benefit checks were mailed directly to the student each month, separate from payments delivered to the rest of her family. ${ }^{12}$ Benefits continued until the beneficiary left college, married or turned 22. ${ }^{13}$ Students were not required to maintain a specific grade point average in order to continue receiving benefits.

Student beneficiaries were eligible for all traditional forms of federal student aid. In 1978, onequarter of youth receiving Social Security Student Benefits also received Basic Educational Opportunity Grants, the precursor to Pell Grants. Because the formulas that determined eligibility for federal aid counted Social Security benefits as family income rather than aid, each dollar of student benefits reduced by only about a nickel the amount of other federal aid a student could receive. ${ }^{14}$

\section{Identification Strategy}

I use difference-in-differences to analyze the effect of the Social Security Student Benefit Program. Cohorts who were high school seniors before 1982, the year in which the program was eliminated, form the "before" group. Younger cohorts, who were seniors in 1982 and later, form the "after" group. The group eligible for aid during the "before" period but not the "after" period is the children of Social Security beneficiaries; I will refer to this as the treatment group. The control group is all other children. The treatment whose effect the paper measures is eligibility for student benefits.

\footnotetext{
${ }^{12}$ Before 1972, the student benefit was bundled into the family's benefit check.

${ }^{13}$ If a youth turned 22 while in school, benefits were continued until the end of the semester.

${ }^{14}$ If benefits had counted as student aid, they would have reduced a student's other federal aid dollar-fordollar. Colleges had to define Social Security as income when distributing federal aid, but may have chosen to offset their own aid offers aid by the amount of a student's Social Security benefits. This "crowd-out" of institutional aid would tend to bias toward zero my estimate of the effect of aid eligibility on attendance.
} 
The key estimating equation is the following:

$$
\text { (7) } y_{i}=\alpha+\beta\left(S S_{i} * \text { Before }_{i}\right)+\delta S S_{i}+{\text { B } \text { Before }_{i}+v_{i}}
$$

where the dependent variable is a measure of college attendance or completion. $S S_{i}$ is a binary variable that is set to one if a youth is the child of a Social Security beneficiary and zero for all other youth.

Before $_{i}$ is a binary variable that is set to one if a youth was a high school senior in 1979, 1980 or 1981 and set to zero if a youth was a high school senior in 1982 or 1983. This specification controls for time trends in college attendance, as well as for the average effect on attendance of being the child of a Social Security beneficiary.

The reduced-form effect of Social Security Student Benefits is identified by $\beta$. The identifying assumption is that any relative trend in the attendance of the children of Social Security beneficiaries is attributable to the withdrawal of student benefits. Note that $\beta$ captures the effect of aid eligibility rather than aid receipt on schooling decisions. From a policy perspective, this is the treatment of interest. Policymakers can control the offer of aid but not its take-up, since take-up is conditional on the eligible youth choosing to go to college.

A youth is eligible for Social Security Student Benefits for one of three reasons: the death, disability or retirement of a parent. In the empirical analysis, I limit the treatment group to those potentially eligible for Social Security benefits due to the death of a parent. ${ }^{15} \mathrm{I}$ do so for two reasons. First, changes in eligibility requirements for Social Security disability benefits in the early 1980s affected the financial status of disabled-worker families independent of any changes in the student benefit program. Second, a parent's decision to enter (or exit) the disability or retirement rolls might be affected by the availability of the student benefit. For example, a father may choose to remain in the workforce longer if student benefits are not available for his college-age child than he would if those benefits were available. ${ }^{16}$ Under this

\footnotetext{
${ }^{15}$ Due to data limitations, those who are child beneficiaries due to the retirement or disability of a parent are in the control group. As will be discussed later in the paper, this misclassification has little impact on the estimates of interest.

${ }^{16}$ In future work, I plan to examine the incentive effects of Social Security Student Benefits on parental labor supply.
} 
scenario, the $\beta$ estimated by Equation (7) will confound the effect of aid eligibility on a youth's schooling with its effect on her parent's retirement or disability status. By contrast, the population of families with a dead parent is unaffected by the availability of student benefits: ex post, death is inarguably exogenous to the generosity of survivor benefits and, ex ante, a change in benefits is unlikely to alter the composition of parents that die. ${ }^{17}$

The data set used in the analysis is the National Longitudinal Survey of Youth (NLSY), a survey of young men and women spanning the years 1979 to 1996 (see the Data Appendix for details). The NLSY does not provide a variable indicating whether a respondent was eligible for Social Security Student Benefits. But, in 1988, respondents answered a series of questions that allow the construction of a variable that indicates whether a child's father died before the child was $18 .{ }^{18}$ I use this variable to proxy for Social Security eligibility in Equation (7):

$$
\text { (7') } y_{i}=\alpha+\beta\left(\text { FatherDeceased }_{i} * \text { Before }_{i}\right)+\delta \text { FatherDeceased }_{i}+{\text { B } \text { Before }_{i}}_{i}+v_{i}
$$

About five percent of respondents had a male parent die before the respondent turned 18. To check on the plausibility of this estimate, I examined the Social Security Administration's mortality tables for men from the 1930 birth cohort, who are about the age of the NLSY's fathers. Of men in this cohort who were alive in 1960, the midpoint of NLSY births, six percent were dead 18 years later. The NLSY data therefore appears to be representative of this cohort of children and their fathers.

Because not all deceased fathers had work histories that entitled their survivors to Social Security benefits, the treatment group is measured with error. Mismeasurement of the treatment group is not a major problem, however. In 1983, 95 percent of children under 18 would have been eligible to receive

\footnotetext{
${ }^{17}$ The elimination of benefits could affect a parent's pre-death behavior in another way: parents may choose to increase their life insurance coverage. This has the potential to decrease the effect of the elimination of student benefits in the long run.

${ }^{18}$ I focus on fathers because about 90 percent of student beneficiaries were entitled through their fathers (Table 93, Social Security Administration [1982]).
} 
survivor benefits upon the death of a working parent. ${ }^{19}$ Later in the paper, I will discuss how to adjust coefficient estimates for any mismeasurement of both the treatment and control groups.

I use ordinary least squares (OLS) to estimate Equation (7’). I also test for robustness of the results to non-linear transformations by applying probit analysis to the estimating equations. Standard errors in the tables are corrected for within-household correlation in error terms due to the presence of sibling pairs in the data, as well as for the heteroskedasticity produced when OLS is applied to dichotomous dependent variables. ${ }^{20}$

\section{The Effect of Aid on Attendance Rates and Completed Education}

In this section, I examine how aid eligibility affects the probability that a given youth will attend college. The impact of aid eligibility on completed schooling is also explored. For both of these outcomes, I test the sensitivity of my estimates to measurement error and alternate definitions of the treatment group.

Sample means for the treatment and control groups, before and after benefits were eliminated in 1982, are presented in Table 1. Youth with deceased fathers were more likely than youth with living fathers to live in low-income families, both before and after the policy change. They were also far more likely to live in single-parent households, explaining much of the income differential. ${ }^{21}$ Children with deceased fathers were also more likely to be nonwhite, due to the higher mortality rate of prime-age black men. Parental education was somewhat lower among youth with a deceased father. For most of these

\footnotetext{
${ }^{19}$ Personal communication with Jeff Kunkel of the Social Security Administration's Office of Research, Evaluation and Statistics. The insured rate is high because the work-history requirements for survivor benefits are relatively lenient. A parent needs to have worked in covered employment only six quarters in the three years preceding death in order to generate minimum benefits for his survivors.

${ }^{20}$ Because the NLSY was initiated as a household survey, there are multiple sibling pairs in the sample. While there are 3,545 people in my main sample, they lived in just 2,500 households in the first year of the survey.

${ }^{21}$ Since some women remarried after their husband's death, not all children with deceased fathers live in single-parent households. Children continued to be eligible for survivor benefits if their mothers remarry.
} 
variables, the differences between the two groups are relatively stable across time and thus will not bias the estimates if the additivity assumption of difference-in-differences is met.

However, for a few key characteristics, the differences between the groups change over time. In particular, the average Armed Forces Qualification Test (AFQT) score of the treatment group was 2.3 points lower than the control group's before the policy change but 9.7 points lower after the policy change. Also, the younger cohort of children with deceased fathers was more likely to be black (31 percent) than the older cohort (24 percent), while there was a much smaller shift over time in the racial composition of children with living fathers. As the last column of Table 1 shows, none of these relative changes in sample means is statistically significant. In the analysis, I will test for whether the results are sensitive to these fixed and changing differences between the two groups.

\section{Attendance Results}

Table 2 contains the probabilities of attending college full-time by 1996, for the treatment and control groups, before and after Social Security benefits were withdrawn. For the cohort of students who were high school seniors in 1979, 1980 and 1981, those with deceased fathers were more likely to attend college than their classmates: 62.5 percent had attended college by 1996, while 53.9 percent of seniors with living fathers had done so. For the younger cohort of students, who were seniors in 1982 and 1983, the pattern is reversed: only 32 percent of seniors whose fathers had died by the time they were 18 went to college, while 49 percent of their classmates attended. The probability of college enrollment dropped by nearly half for the group with deceased fathers (31 percentage points), while it barely dropped for other students (5 percentage points).

The estimated effect of eligibility for Social Security Student Benefits on the probability of attending college is the difference in these two differences: 26 percentage points. We can also calculate this difference-in-differences estimate by running Equation (7') as an ordinary least-squares regression, shown in Column (1) of Table 3. The estimate of 25.6 percentage points is highly significant, with a standard error of 10.0 percentage points. The probability of attending college by 1996 in this sample is 53 
percent, indicating that benefits had a very large relative effect on attendance rates. It should be recalled at this point that the benefits offered by the program were quite sizable, and so a response of this magnitude is plausible. Later in this section, I will place this attendance response in perspective by calculating the implied elasticity of attendance with respect to schooling costs.

It is possible that the estimate is picking up differences between the treatment and control groups that affect time trends in college attendance. In order to test for such bias, I add a set of covariates to Equation (7'). This specification controls for family income, measured at the time the respondent was a high school senior and converted to 1998 dollars. ${ }^{22}$ Family size and AFQT score are also added, along with dummies indicating year of birth, race and a household headed by a single parent. Two dummy variables indicate whether an individual's mother and father have completed any college and dummies indicate whether either of these pieces of information is missing.

Results for this specification are in Column (2) of Table 3. The explanatory power of the equation rises substantially with the addition of covariates, from 0.005 for the baseline specification to 0.294 for the richer specification. However, the point estimate is barely affected, dropping insignificantly from 25.6 percentage points to 23.3 percentage points. The estimate is somewhat more precise, with a standard error of 8.7 percentage points. As a result, the estimate is still significant at the one-percent level.

Conditional on covariates, the effect of having a deceased father is not significantly different from zero (-6.8 percentage points with a standard error of 7.1). That is, once we control for observables, the treatment group is statistically similar to the control group in its college-going rate except for the difference induced by student benefit eligibility, as captured by the interaction term. A large and significant coefficient on the treatment dummy would signal differences between the treatment and control groups that could induce a divergence in their attendance trends as well as their levels, thereby violating the difference-indifferences identifying assumption.

\footnotetext{
${ }^{22}$ For those cases where family income is missing, the missing value is set to the sample mean. A dummy indicating these imputed values is included in the regression.
} 
The estimates so far have controlled only for average differences between the treatment and control groups. A potential pitfall of this approach is that the relationship between these characteristics and college-going may change over time. For example, youth with a deceased father are disproportionately black. College enrollment rates of blacks dropped during the early 1980s (see Kane [1994]), and since this drop coincides with the elimination of Social Security Student Benefits, the estimate may simply be picking up secular trends in the college attendance rate of blacks. Similarly, since the income of deceased-father families is substantially lower than that of the control group, the estimate may be capturing a time trend in the effect of income on college attendance. In particular, if the college attendance of youth from lowincome families is particularly sensitive to the business cycle, then the estimate of Column (2) may confound the effect of aid with the effect of the 1981-82 recession.

To test for such confounding trends, I allow the effect of covariates to vary with time. Family size, family income, AFQT, parental education, race and the variable indicating a single-parent household are all interacted with the "before" dummy, thereby allowing their effects to differ during the periods before and after the policy change. ${ }^{23}$ Column (3) of Table 3 presents these results. The estimate of the effect of aid on attendance drops only slightly, from 23.3 to 19.4 percentage points, and is still significant at the 5 percent level. As expected, the results pick up a downward trend in the attendance of blacks, though the coefficient is not significant. The effect of income does not appear to vary with time. ${ }^{24}$

Meyer (1995) points out that difference-in-differences estimation can be sensitive to non-linear transformations of the dependent and independent variables. The results discussed so far suggest that this is unlikely to be a problem. An examination of the simplest difference-in-differences estimate in Table 2

\footnotetext{
${ }^{23}$ The dummies indicating missing data are also interacted with time.

${ }^{24}$ I have also run a version of the specification in Column (3) that includes dummies indicating nominal household income below $\$ 10,000, \$ 20,000, \$ 25,000, \$ 30,000$ and $\$ 40,000$, along with their interaction with the "before" dummy. This set of variables corresponds to income eligibility cutoffs for need-based federal aid. Since the cutoffs changed during the period under study, due to the repeal of the Middle Income Student Assistance Act, excluding them potentially biases the results. The results are unaffected by the inclusion of these variables.
} 
shows that the children of deceased fathers were more likely that their counterparts to attend college before the policy change but less likely to attend college afterward. This simple fact will persist whether we estimate our equations using linear or non-linear methods. Linear and nonlinear analysis will therefore produce estimates of consistent sign, though their magnitude may vary with the method of estimation.

Table 4 compares OLS and probit analysis of Equation (7'). In Column (1) are the OLS estimates from the previous table, while the probit coefficients are in Column (2) along with their standard errors. The predicted marginal effect of the coefficient of interest is presented in Column (3). The OLS estimates and predicted probit effects are quite similar. The simplest difference-in-differences estimate is the same for both OLS and probit: 25.6 percentage points. This to be expected, as probit and OLS are computationally identical when the model is fully saturated, i.e., when the specification consists of dichotomous variables and a complete set of their interactions. The probit results are somewhat more robust to specification than the OLS results. The addition of demographic controls barely alters the probit estimate, while interacting these controls with a time dummy reduces the probit estimate to 24.8 percentage points.

I also test the use of a fixed-effects, within-family estimator. Since the NLSY is a householdbased survey; every youth of the appropriate age within a given household is in the sample. We can therefore control for unobserved differences between families by including in the regression a householdspecific fixed effect. The source of identification is then the difference between the college attendance rates of younger and older siblings in deceased-father households, relative to the difference between younger and older siblings in living-father households. ${ }^{25}$ The estimates (not shown) are similar to those we have already seen, though they are generally insignificant. The most fully-controlled specification produces

\footnotetext{
${ }^{25}$ Birth order may have a differential effect on the college attendance of children in deceased-father households, which would confound this estimation strategy. For example, an older sibling may feel pressure to skip college in order to financially support the family after his father dies. However, the fixedeffects estimates, along with all of the paper's results, are robust to the addition of controls for birth order and its interaction with having a deceased father.
} 
an estimate of 22.7 percentage points, with a standard error of 16.3 percentage points. ${ }^{26}$ This suggests that time-varying, unobserved differences between households with living and dead fathers are not driving the results of the previous tables.

\section{Interpretation of Attendance Results}

To summarize, the estimated effect of the Social Security Student Benefit Program on college attendance probabilities is robust to specification and functional form. Adding a rich set of covariates to the difference-in-differences regression does not substantially affect the coefficient of interest, nor does allowing the effect of these variables to vary with time. Further, the estimates produced by OLS, probit and fixed-effects analysis are almost identical. The estimates suggest that eligibility for the program increased the college attendance rate by 19.4 to 25.6 percentage points.

This is a substantial gain, given the average attendance rate of 53 percent during this period. We can scale this effect against the generosity of the program. The average Social Security Student Benefit paid in 1980 to the children of deceased parents was about $\$ 6,300 .{ }^{27}$ The midpoint of the estimates implies that each $\$ 1,000$ of student benefits induced an increase of 3.6 percentage points in the share of high school graduates who attended college by 1996. In this particular case, this calculation of the effect of $\$ 1,000$ of aid has an instrumental variables interpretation: it is the Wald estimate. Assuming that the effect on attendance is linear and constant across individuals, this estimate is computationally equivalent to one obtained by using FatherDeceased $_{i} *$ Before $_{i}$ as an instrument for aid in a schooling equation.

We can further scale these effects by calculating an elasticity. During this period, the average cost of tuition, fees, room and board was about $\$ 9,600$ (College Board, 1983). Focusing on the midpoint of the estimates, the implied elasticity of college attendance with respect to college costs is about 0.65 .

\footnotetext{
${ }^{26}$ The specification is that of Column (3) in Table 3, with the addition of a household fixed effect.

${ }^{27}$ As was stated earlier in the paper, the average benefit paid to all Social Security Student Beneficiaries in 1980 was $\$ 5,400$. The children of deceased workers received benefits that were, on average, higher than those paid to the children of retired and disabled workers.
} 
How do these figures compare with previous estimates of the effect of college costs on attendance? Leslie and Brinkman's review (1988) of college attendance studies concludes that a $\$ 1,000$ increase in net price is associated with a three to five percentage point decrease in the attendance of 18to 24-year-olds. Manski and Wise (1983) predict that $\$ 1,000$ in aid will lead to a 3.8 percentage point increase in attendance. Kane (1994) concludes that a \$1,000 increase in public tuition will result in a 3.7 percentage point decrease in college attendance. Reyes (1995) finds only a 1.5 percentage point effect of $\$ 1,000$ in loan subsidies. The present estimate, then, is consistent with most estimates produced by earlier studies.

\section{Measurement Error in the Classification of the Treatment and Control Groups}

As was discussed earlier, the treatment group is measured with error. For example, some fathers did not work in employment covered by Social Security and their children were therefore not eligible for survivors' benefits. The control group is also measured with error, as it contains some children of retired or disabled parents who were eligible for student benefits and therefore rightly belong in the treatment group. ${ }^{28}$ Let $\boldsymbol{\delta}_{T}$ be the share of children with deceased fathers who are not eligible for Social Security benefits - that is, $\delta_{T}$ is the degree of classification error in the treatment group. Let $\boldsymbol{\delta}_{C}$ be the share of children without deceased fathers who are eligible for Social Security benefits - that is, $\delta_{C}$ is the degree of classification error in the control group. Aigner (1973) and Freeman (1984) show that the relationship

\footnotetext{
${ }^{28}$ The NLSY contains no information about parents' retirement or disability status, so these individuals cannot be identified. The discussion that follows assumes that these individuals would have had the same response to the elimination of benefits as the children of deceased parents. This assumption is not precisely correct, for two reasons. First, the children of disabled and retired parents were eligible for only two-thirds of the benefits of the children of deceased parents. If we assume that the attendance response is linear in benefits, we can account for this lower benefit in our estimates; doing so has an insignificant effect on the error adjustment discussed in this section. Second, the withdrawal of student benefits may have altered the population of retired and disabled beneficiaries by reducing the incentives for parents of college-age children to apply for Social Security. There is no simple solution to this problem. But this problem is unlikely to have a major impact on the error adjustment, since such a small proportion of the control group is incorrectly classified.
} 
between the coefficient estimated in the absence of classification error $\left(\beta^{*}\right)$ and the coefficient estimated in the presence of classification error $(\beta)$ is given by:

$$
\text { (8) } \beta^{*}=\frac{\beta}{\left(1-\delta_{T}-\delta_{c}\right)}
$$

The estimated coefficient is therefore biased toward zero by classification error. This result may seem obvious, since classical measurement error is known to produce attenuation in regression coefficients. However, measurement error in binary variables is non-classical: if a zero is observed, the measurement error can only be non-negative and if a one is observed the measurement error can only be non-positive. This violates the standard assumption that the measurement error is uncorrelated with the truth. ${ }^{29}$

Misclassification of the treatment group is minor. The Social Security Admnistration estimates that in the early 1980s 95 percent of children under 18 would have been eligible for survivor benefits had a working parent died. I therefore assume that $\delta_{T}$ is $0.05 .{ }^{30}$ Misclassification of the control group is also minimal. I calculate this source of error as the share of 17-year-olds in 1980 whose fathers are not dead and who are eligible for Social Security due to the disability or retirement of a parent. Combining data from the 1980 Census and the Social Security Administration, I calculate that 5.3 percent of 17 -year-olds fall into one of these two categories, implying a misclassification rate of 0.053 for the control group. ${ }^{31}$ Combining the two misclassification rates produces a value for $1-\boldsymbol{\delta}_{T}-\boldsymbol{\delta}_{c}$ of 0.897 .

To adjust for classification error the point estimates of previous tables should be multiplied by the inverse of this number, which is 1.11. Applying this upward adjustment of 11 percent to the coefficients of

\footnotetext{
${ }^{29}$ Note that Equation (8) holds for bivariate regressions and in the special multivariate case where the classification variable and its error are uncorrelated with other regressors. In the general multivariate case the degree of attenuation bias worsens. As I have no information about how classification error correlates with covariates, I am limited to the adjustment of Equation (8).

${ }^{30}$ Assuming high values for $\boldsymbol{\delta}_{T}$ and $\boldsymbol{\delta}_{C}$ will lead to large upward adjustments in the point estimate, hence my conservative assumptions about the degree of measurement error.

${ }^{31}$ The number of 17-year-olds in 1980 is drawn from the 1980 Census. The number of 17 -year-olds receiving benefits in 1980 due to the retirement of disability of a parent is drawn from Social Security Administration (1982), Table 54.
} 
Table 4 (19.4 to 25.6 percentage points) yields error-adjusted estimates of 21.5 to 28.5 percentage points. These average of the three estimates corresponds to an increase in the attendance rate of four percentage points for each $\$ 1,000$ in aid eligibility. This corresponds to an elasticity of attendance with respect to schooling costs of 0.72 .

\section{Completed Education Results}

Having established that the Social Security Student Benefit Program likely had a large and statistically significant effect on college attendance, I now explore whether this increased attendance translated into higher levels of completed education. The federal student aid programs are motivated by a goal of expanding the college-educated population. However, persuading a student to enter college does not guarantee that he will successfully complete even one year. If the marginal student is of low ability and is therefore unable to complete college-level work, the social benefits of the program will be lower than an analysis focused on attendance would suggest. ${ }^{32}$

I focus on the highest grade a person has completed by 1996, the last available survey year. The highest grade completed ranges from the $11^{\text {th }}$ (for those who did not complete their senior year of high school) to the $20^{\text {th }} .{ }^{33}$ These figures refer to a person's years of "regular" schooling and therefore exclude on-the-job training and other non-traditional programs. In Table 5 are the means of completed education for the children of deceased fathers and all other individuals, before and after Social Security Student Benefits were eliminated. For the cohort that was of college age college while benefits were in place, average education in the treatment and control groups is quite similar: 14.04 years for the children of deceased fathers and 13.95 for all others. For the cohort that was of college age after benefits were eliminated, there is a relatively large gap in average education levels: 12.90 years for the children of

\footnotetext{
${ }^{32}$ Note that the grade completion and college attendance variables are constructed from separate questions in the NLSY. In fact, a person who has attended college may have completed no college.

${ }^{33}$ Since my "before" dummy is defined by the year a youth was a high school senior, all those in my sample have completed at least 11 years of school.
} 
deceased fathers and 13.76 for all others. Based on these means, the difference-in-difference estimate of the effect of aid eligibility on completed schooling is 0.95 years.

Table 6 contains results of making this same calculation using OLS. The estimate is 0.948 , with a standard error of 0.367 . The estimate is significant at the one-percent level. Column (2) adds to the regression the same set of covariates used in the attendance analysis. While the explanatory power of the estimating equation rises sharply, from 0.004 to 0.375 , the estimate is relatively stable at 0.844 . Adding interactions of covariates with time in Column (3) produces a coefficient of 0.811 (with a standard error of 0.376). Adding a household-specific fixed effect to this last specification (results not shown) barely alters the estimate to 0.830 but substantially increases its standard error to 0.640 . As was the case with attendance, the grade completion estimates are robust to the addition of a rich set of covariates.

Applying the adjustment for measurement error to these results yields an estimated program effect of 0.90 to 1.05 years of schooling. The midpoint of these estimates implies that for each $\$ 1,000$ of benefits completed schooling increases 0.16 years. To place the results in perspective, note that average years of schooling completed by the NLSY sample in 1996 is 13.89 years, or 1.89 years of post-secondary schooling. This implies that the Social Security Student Benefit Program increased the average number of years of post-secondary schooling by 53 percent. Again assuming average schooling costs of $\$ 9,600$ and average benefits of $\$ 6,300$, this implies an elasticity of years of completed college with respect to cost of about 0.8 .

\section{Expanding the Treatment Group}

So far, I have limited the treatment group to those youth potentially eligible for Social Security Student Benefits due to the death of their fathers. As was discussed earlier, the composition of the population with a dead parent is unlikely to change in response to the withdrawal of benefits. By contrast, the population with a retired or disabled parent may change when benefits are withdrawn, since their elimination makes retirement or disability less financially attractive to families whose children are likely to attend college. Despite this potential problem of endogenous selection into the treatment group, it is of 
interest to examine whether the response of other eligible youth is at least roughly similar to that of the deceased-father group.

I use father's age as a rough proxy for his retirement status. Retirement probabilities rise sharply at 65 (Lumsdaine, Stock and Wise [1996]). In 1980, 60.8 percent of men 60 to 64 years old were in the labor force, compared to only 28.5 percent of men 65 to 69 years old. ${ }^{34}$ Whether a man is over 65 therefore seems a reasonable proxy for his retirement status. I define a retirement-age father as one who turned 65 before or during the year in which the youth was a high school senior.

In order to check if expanding the treatment group substantially alters the results, I combine the groups with deceased and retirement-age fathers for the analysis in Table $7 .^{35}$ In the first row of each panel are reproduced the results obtained when the treatment group is limited to those with a deceased father. In the second row the treatment group is those with a father who is either of retirement age or deceased. Expanding the control group in this way decreases the standard errors of the estimates slightly, but has little effect on the estimates themselves. ${ }^{36}$

These results show that during the early 1980s college attendance and completed education dropped among the children of both retirement-age fathers and deceased fathers. This suggests that the main results of the paper are not the product of some spurious trend in the educational choices of youth with deceased fathers. Having established the shared response of the two groups to the withdrawal of aid,

\footnotetext{
${ }^{34}$ I am grateful to Courtney Coile for providing these figures, which are drawn from Bureau of Labor Statistics data.

${ }^{35}$ I combine the two groups because the sample with a father of retirement age is too small to allow for informative analysis. Only about a third as many youth have a father of retirement age as have one who is deceased. Point estimates based on the older-father treatment group are of the expected sign and magnitude but are not statistically significant.

${ }^{36}$ Since the results suggest that the two groups had roughly similar overall responses to the elimination of benefits, the per-dollar response of the retired-father group must be relatively high, since on average they were eligible for relatively low benefits $(\$ 4,400$ a year, as compared to $\$ 6,300$ for those with a deceased father).
} 
the remainder of the paper will focus on the deceased-father group, since for this population issues of identification and interpretation are relatively clear-cut.

\section{The Effect of Aid on the Distribution and Timing of Educational Investment}

The analysis so far has focused on how aid eligibility affects the mean level of education. But a given increase in average schooling can result from very different shifts in the educational distribution. For example, an increase in average schooling of one year can arise because everyone increases their schooling by one year, or because one-half of the population increases schooling by two years while the other half experiences no increase at all. Determining which of these is the case allows policy-makers to understand how altering aid policy will affect the distribution of education in the population. Further, it offers some insight into the type of student whose behavior is affected by financial aid policy.

In Figures 3A through 3D, I plot a series of distributions. These graphs depict the distribution of completed schooling in 1996. They are unconditional distributions, obtained from a simple tabulation of the weighted sample. Figure 3A plots the distribution of completed education for those whose fathers were not deceased (the control group). The dotted line is the distribution for those members of the control group that were high school seniors from 1979 to 1981, when Social Security Student Benefits were still in place. The solid line graphs the distribution for those members of the control group who were seniors after benefits were eliminated. The two lines track each other quite tightly, indicating that there was very little change during this period in the distribution of education within the control group.

Figure 3B plots the corresponding distribution for the children of deceased fathers. Here we see a marked shift across cohorts in the distribution of education. For those members of the treatment group who were seniors before the Social Security Student Benefit Program was eliminated, only about 38 
percent had completed twelve or fewer years of education by 1996. After the program's elimination, 62 percent of this group completed twelve or fewer years. ${ }^{37}$

We can take the difference between the two lines in Figure 3B in order to ease the comparison of the two cohorts. This difference for the treatment group is plotted as the solid line in Figure $3 \mathrm{C}$; the control group difference is the dotted line. ${ }^{38}$ A positive point indicates that the share of the population at that level of education is higher for the "before" group than the "after" group. For example, the positive area at fifteen and sixteen years for the treatment group indicates that more of its "before" cohort, which was eligible for benefits, completed three to four years of college than did the cohort that was ineligible. The flatness of the line for the control group indicates that its educational distribution did not change across cohorts, as we saw in Figure 3A.

The lines in Figure 3C are a visual representation of the differences of Table 5. In that table, we saw that the across-cohort change in years of completed education for the control group was very small, 0.19. The dotted line in Figure 3C displays the full distributional shift that lies behind that difference in means. In fact, integrating over the dotted line, weighting appropriately by cell size, will yield exactly the difference of 0.19. Similarly, integrating over the solid line will yield the difference for the treatment group, 1.13 .

Just as we take the difference of differences in means in Table 5, we can take the difference of the differences in distributions plotted in Figure 3C. Figure 3D graphs the difference between the two lines shown in Figure 3C. The point-wise 95 percent confidence interval is also plotted. Figure 3D is a visual

\footnotetext{
${ }^{37}$ A comparison of these numbers with those in Table 2 yields an apparent inconsistency: the share of respondents that has completed some college by 1996 is higher than the share that has attended college. However, the attendance variable is positive only when an individual has gone to college full-time, as only full-time students were eligible for Social Security Student Benefits. Those who advance in college solely through part-time enrollment will therefore show up in the grade completion variable but not in the attendance variable. Further, the NLSY is administered in the first few months of the year and therefore misses the attendance of those who enroll in September and drop out by spring.

${ }^{38}$ The distributions of the "after" cohorts have been subtracted from those of the "before" cohorts.
} 
representation of the difference-in-differences estimate. Integrating over this function (again, properly weighting by sample size) will yield the difference-in-differences estimate of 0.95 shown in Table 5 .

In Figure 3D, we can identify the shifts in the educational distribution induced by Social Security Student Benefits. The negative area at twelve years indicates that benefits encouraged individuals who would have otherwise stopped their education at high school to continue on to college. The positive area at fifteen and sixteen years of schooling indicates that benefits increased the share that obtained three to four years of college. Points near zero (for example, at 13 and 14 years of schooling) indicate levels of education at which the program had a minimal effect on the distribution.

The most significant impact of aid appears in two places: at college entry and at three to four years of college. The graph is consistent with a scenario in which aid pushes everyone up the distribution, causing those who would have stopped at high school to instead complete one to two years of college and causing those who would have stopped at one to two years of college to instead complete three to four years. ${ }^{39}$ While this story is plausible, the graph is equally consistent with a scenario in which those who would have stopped at high school instead complete three to four years of college and those who would have stopped at one to two years of college continue to stop at one to two years of college. The former scenario - that aid pushes everyone up the educational distribution - makes more economic sense and is my preferred explanation for the shifts depicted in Figure 3D.

\section{The Timing of Educational Investment}

The panel structure of the NLSY allows us examine the effect of aid on the lifetime pattern of educational investment. We might suspect, for example, that a program that pays benefits only until age 22 will encourage youth to obtain their education relatively early. In Figure 4A is graphed the average education, by age, of the cohort that was in its senior year of high school between 1979 and 1981 (the

\footnotetext{
${ }^{39}$ In other words, aid may have a monotonic effect along the educational distribution. Assuming monotonicity allows us to use the elimination of the aid program as an instrument for education (for example, in an earnings equation) and then interpret the resulting coefficient on education as an average causal response. See Angrist and Imbens (1995).
} 
"before" cohort). The means are plotted separately for the children of deceased fathers and all other individuals. The most striking fact is that the two lines track each other very tightly. For both groups, educational investment is concentrated in the years before age 23. But education continues to rise at a slow pace until age $31 .^{40}$ On average, education rises half a year between the ages of 23 and 31, from 13.4 to 13.9 years. There is no evidence in this graph that those eligible for student benefits were any more likely than the average student to get their college education before age 22, when benefits ran out.

Graphs for the cohort in its senior year of high school after Social Security Student Benefits had been eliminated are plotted in Figure 4B. The control group's age pattern of education is almost identical to that seen in Figure 4A. But the treatment group's pattern of educational investment is dramatically different. By age 23, there is a large gap between the two groups. The gap widens as the cohort ages, as the control group continues to invest in education while the treatment group does not. Fully one-third of the final gap between the two groups accrues after age 23 .

Can we attribute this flattening of the age profile of educational investment to the withdrawal of aid? Answering this question requires a closer examination of how the affected cohorts altered their schooling choices. It is implausible, for example, that aid offered before age 23 would induce individuals to begin college at age 27. Examining the relative shifts in the educational distribution as of the cohorts' early twenties and as of their early thirties will allow us to gauge whether they can be attributed to aid that is offered between age 18 and 22 .

In Figure 5 are plotted the differences-in-differences of the distributions of completed education at age 23 (right after Social Security benefits expire) and age 31 (the end of the sample). We would like to interpret these two lines as the effects of aid eligibility on the distribution of education at age 23 and age 31. Gaps between the two lines can be interpreted as the effect of aid eligibility on changes in the distribution of education between ages 23 and 31. Points on the graph where the dotted line is above the

\footnotetext{
${ }^{40}$ The youngest members of the NLSY are 31 in 1996, and so we cannot extend the analysis beyond that age.
} 
solid line indicate where aid eligibility has increased the share of individuals with that level of education at age 31 relative to the share with that level at age 23 .

The two lines are quite close at twelve years of schooling, indicating that aid eligibility does not alter the college entry rate between age 23 and age 31 . But among those who had attended college by age 23, aid eligibility does appear to have increased the rate of subsequent educational investment, causing those who had completed one to two years of college at age 23 to add another year or two by age 31 . In other words, students who were induced by aid to enter college were more likely to go on in college later in life than those who never entered.

This pattern is consistent with an economic model in which there are fixed costs to college attendance, such as entrance exams, applications, the development of study skills and perhaps determining one's academic ability. A person who has completed some college and another who has finished only high school face different costs for an additional year of schooling: The first faces only the marginal cost of an additional year, while the second must pay both fixed and marginal costs in order to start college. The evidence suggests that, by subsidizing the fixed costs of college, aid can have a "threshold effect," pushing students over the hurdle of college entry. An efficient aid policy would therefore be one that is relatively generous for the first year of college and then tapers off. The new federal Hope Scholarship uses this approach, offering tax breaks for only the first two years of college. Many schools follow a similar strategy, offering lucrative grants to entering freshmen and less generous aid packages to upperclassmen.

\section{Additional Evidence on the Schooling Choices of Student Beneficiaries}

The analysis so far has focused on the effect of aid on educational attainment and completion. But aid may affect other dimensions of the schooling decision. For example, aid may not only increase the number of years of college completed but the quality of college attended. Similarly, aid may shift students from public into private schools or from two-year into four-year colleges. The NLSY contains detailed information about individual schooling choices. But the population with deceased fathers in the NLSY is too small to allow for informative examination of the impact of aid on finer details of schooling choice. 
Fortunately, administrative data allow us to at least paint a broad picture of the schooling choices of Social Security Student Beneficiaries. In 1972, the Social Security Administration commissioned a survey of student beneficiaries, gathering information about their schools, grades and family backgrounds. The survey was conducted only in one year, and was limited to those who actually took up student benefits by attending college. While these limitations preclude using the data in a formal difference-in-differences analysis, the survey can give us a sense of the schooling choices made by beneficiaries, which we can then compare to those of other youth. ${ }^{41}$

Student beneficiaries during the 1972-73 academic year look much like the average young college student. Seventy-four percent of college-going beneficiaries attended four-year institutions, as compared to 72 percent of all college students. ${ }^{42}$ A somewhat higher share of student beneficiaries than all full-time, young college students attended private schools: 29 and 18 percent, respectively. ${ }^{43}$ They were similarly successful in their academic endeavors: 50 percent of student beneficiaries maintained a B average or better during their freshmen year, while 54 percent of college freshmen in the National Longitudinal Survey of the High School Class of 1972 did so (Springer, 1976).

Recall that the Social Security program provided a flat benefit, regardless of actual schooling costs. This may have induced some students to choose inexpensive and undemanding schools so that they could collect their benefits with minimal effort. Note that beneficiaries had to attend school full-time to collect their benefits. Further, working full-time and collecting student benefits on the side was not a very

\footnotetext{
${ }^{41}$ The Social Security Administration has been unable to find a copy of this data-set in their archives. However, detailed tabulations of the data were published (Springer [1976] and Hastings [1978]), and it is from these sources that I draw the statistics in this section.

${ }^{42}$ Calculated from data in Table 18 in Bureau of the Census (1974) and Chart 1 in Springer (1976). Note that the Census figures for this period do not measure enrollment in non-degree programs, such as those in secretarial or technical schools. To maintain comparability, I have similarly excluded such students from the student beneficiary enrollment figures.
}

${ }^{43}$ Calculated from data in Table 12 in Bureau of the Census (1974) and Table 9 in Springer (1976). This figure includes those in non-degree programs, since a separate private/public breakdown is not provided for just those in degree programs. 
lucrative option, since there was a fairly low cap $(\$ 6,600$ in 1972$)$ on the amount a youth could earn and still collect full benefits. ${ }^{44}$ The schooling choices of beneficiaries do not indicate that they sought out the cheapest and easiest schools. We have seen that they attended private and four-year institutions at similar rates as other college students. Student beneficiaries spent also about the same as the average student on tuition, fees and books: $\$ 2,500$ for those attending public schools and $\$ 7,900$ for those attending private schools, as compared to $\$ 2,200$ and $\$ 8,000$ for all full-time post-secondary students. Adding in room and board brings the average educational cost for all student beneficiaries to $\$ 8,200$; for all students, the comparable figure is $\$ 7,400$. Note that the average annual benefit paid to student beneficiaries in the survey was $\$ 5,500 .{ }^{45}$

Further, student beneficiaries did not take up all of the subsidies for which they were eligible. The Department of Health, Education and Welfare estimated that 70 percent of student beneficiaries attending college during the academic year 1979-80 were eligible for the Pell Grant. However, only 41 percent even applied for the Pell. Since Pell receipt would not have reduced Social Security benefits, these untapped Pell funds represent money that student beneficiaries simply left on the table. ${ }^{46}$

In summary, those receiving Social Security student benefits made schooling choices much like those of the typical college student. This is remarkable, since the beneficiary population was disproportionately black and low-income. In 1972, 12.5 percent of college-going beneficiaries were black.,

\footnotetext{
${ }^{44}$ Student beneficiaries remained well below the earnings cap, with median annual earnings of $\$ 3,800$ (\$1998) in 1972 (Springer, 1976). A student whose earnings exceeded the cap was required to file an earnings report with the SSA. Earnings records filed by employers were audited to ensure beneficiary compliance.
}

${ }^{45}$ Springer (1976) and Table 309 in NCES (1996). The beneficiary survey lumps tuition, fees and books into one question. The NCES costs for all college students do not include books. For comparability, I have added a $\$ 600$ book allowance to the NCES figures, following Springer (1976).

${ }^{46}$ Committee on Ways and Means (1979). The low Pell take-up rate among student beneficiaries suggests that they were responding to the program's relatively high transaction costs. Application to the Pell required that a student learn about the program and then obtain and fill out a lengthy form with data about family income, assets and expenses. By contrast, youth gained eligibility for Social Security Student benefits by simply responding that they planned to attend college when they received a letter of inquiry from SSA soon before their $18^{\text {th }}$ birthday. 
as compared to 8.3 percent of all college students of the same age.$^{47}$ More than half of college student beneficiaries had family incomes below $\$ 39,000$, while only 35 percent of all families with a full-time student between the ages of 18 and 24 fell into that income range..$^{48}$ That the college choices of this group look much like those of the average student suggests that Social Security Student Benefits influenced not only the level of education chosen but the quality of school attended, as well.

\section{Cost-Benefit Analysis}

The previous sections have shown that the Social Security Student Benefit Program likely produced large increases in the share of youth attending college and in their average number of years of completed schooling. I now undertake a simple cost-benefit analysis in order to determine whether the benefits induced by this increased schooling outweigh its costs. The cost of inducing a student to complete a year of college consists of three elements: the amount of aid delivered to the student, the excess burden on the economy imposed by the taxes that produce pay for aid, and the earnings foregone by the youth attending college. The benefit of inducing an additional year of college consists of the additional earnings enjoyed by the college-educated worker. ${ }^{49}$

Turning first to the costs, we have found that an offer of \$1,000 (\$1998) in aid increases completed schooling by roughly 0.16 years; an offer of $\$ 6,300$ therefore increases schooling by one year. The excess burden imposed on the economy by raising these funds depends on our assumption about the marginal deadweight loss to the economy produced by an additional dollar of taxation. The student benefit program was funded through the same payroll tax that funds all Social Security retirement, disability and

\footnotetext{
${ }^{47}$ Beneficiary figure calculated from data in Table 1 and Table 2 in Huntley (1979). Total enrollment figure calculated from data in Table 1 in Bureau of the Census (1974).

${ }^{48}$ Calculated from data in Table 18 of Bureau of the Census (1974) and Table 17 of Springer (1976).

${ }^{49}$ If education produces either non-monetary benefits for those who are educated or produces positive externalities then this measure will underestimate the benefits of aid. Hartman (1973) provides a useful discussion of the non-monetary benefits of higher education.
} 
survivor benefits. ${ }^{50}$ Fullerton (1991) reviews several papers that estimate that the marginal deadweight loss of the payroll tax and finds that their estimates range from seven to 21 cents. ${ }^{51}$ I will use the highest estimate, which will weigh against finding positive effects of the program. Given a marginal cost of funds of 1.21 the cost of raising $\$ 6,300$ is $\$ 1,300$.

The final and largest cost of an additional year of college is the earnings foregone by a student while she is in college. In 1979, the average 19-year-old high school graduate earned $\$ 16,435$. $^{52}$ I will use this figure to proxy for the opportunity cost of a year of college.

I next turn to the calculation of the increased earnings that accrue to a person from a single year of college. A simple representation of the benefit of one year of college education is:

$$
\int_{a g e=20}^{65} f(S \mid S=13) e^{-r t} d t-\int_{a g e=19}^{65} f(S \mid S=12) e^{-r t} d t
$$

This is present discounted value of the stream of earnings associated with one year of college, less the stream of earnings associated with zero years of college. Note that those with one year of college have one year less of earnings than those with zero years of college, as they start their careers later than those who end their education with high school. This formulation therefore directly incorporates the opportunity cost discussed in the previous paragraph.

I use data from the 1979 through 1991 Current Population Surveys to calculate Equation (9). I focus on those who are age 19 in 1979, constructing a synthetic cohort that spans the years 1979 through

\footnotetext{
${ }^{50}$ The Congressional Budget Office (1977) estimates that each OASDI-covered worker paid about 0.17 percent of his Social Security wages, or $\$ 33$ a year in current dollars, toward payroll taxes for the student benefit program.

${ }^{51}$ These figures apply to the case where revenues are used to fund a public good. In the case at hand, there is a direct linkage between taxes paid and benefits received: covered workers pay Social Security taxes and receive retirement benefits and insurance against death and disability, and potentially aid for their college-going children. Summers (1989) points out that if workers value these benefits, then the inefficiency costs of taxation are relatively low.

${ }^{52}$ Author's tabulation of the Merged Outgoing Rotation Groups of the 1979 Current Population Survey. I use weekly earnings and assume 50 weeks are worked in a year.
} 
$1991 .^{53}$ In each of these years, I separately calculate average earnings for those with 12 and 13 years of completed schooling. After 1991, the CPS stopped gathering information about years of completed college and switched to a question that focuses on degree completion; as a result, I cannot directly measure the wage differential for this cohort after age 31 . In order to sum the earnings effects up to age 65 , I assume that the percentage differential between those with one year of college and no college is constant after age $31 .{ }^{54}$ I assume a discount factor of four percent, and inflate all amounts to their 1998 values using the Consumer Price Index.

Given these assumptions and data, I calculate that in 1979 the present discounted value of the additional earnings enjoyed over the lifetime by a person with a single year of college is $\$ 15,500$. This figure is net of the opportunity cost of one year of college. Given that it cost $\$ 7,600$ to raise and deliver the aid required to induce a year of college , the program was of social benefit, with benefits exceeding costs by $\$ 7,900$.

This calculation assumes that individuals induced to attend college by aid enjoy the same return to college as the average person. But if the marginal student is of low ability, his rate of return to schooling may be lower than average, making the calculation of the previous paragraph an over-estimate of the program's benefits. ${ }^{55}$ I therefore undertake an alternative calculation that does not assume that the return to college of the marginal student is the same as that of the general population. Again using the CPS to construct a synthetic cohort, I calculate the age-specific, mean annual earnings of those with only a high

\footnotetext{
${ }^{53}$ I therefore follow the cohort from age 19 to age 31.

${ }^{54}$ Again, this assumption is a conservative one that will weigh against finding positive effects of the program. The age-earnings profile of the college-educated is steeper than that of the high-school educated, so assuming a constant gap between the two groups after age 35 underestimates the benefits of a college education.

${ }^{55}$ By contrast, if the marginal student is liquidity constrained, his rate of return to schooling may be higher than average.
} 
school degree, summing and discounting these earnings over the lifetime. ${ }^{56}$ Positing a range of values for the rate of return from zero to ten percent, I then calculate the present-discounted value of an additional year of schooling. This approach assumes only that a person who completed one year of college would have made at least as much as the typical high school graduate had she entered the labor force immediately upon graduation.

The results are graphed in Figure 6. At a return to education of zero, there are no benefits while the costs are the grant, the excess burden imposed by taxes that pay for the grant, and one year of lost wages - a net loss of about $\$ 24,000$. At a rate of return of about 4.8 percent, these costs are fully recouped. To put these results in perspective, the range of recent instrumental variable estimates for the rate of return to education is about 7 percent to 15 percent (see Card, 1995). Under most plausible estimates of the rate of return to education, then, the program was a worthwhile investment for the government.

These results suggest that aid can have a Pareto-improving impact on educational investment. As was discussed earlier in the paper, there are at least two reasons why private and social schooling choices might diverge, thereby creating a welfare-enhancing role for aid. Individuals may be liquidity-constrained, and therefore unable to fund their education out of future earnings. And even in the absence of liquidity constraints, risk-averse individuals will invest in a socially sub-optimal level of education if the returns to that education are uncertain. The results of this cost-benefit analysis indicate that one or both of these dynamics is at work.

\footnotetext{
${ }^{56}$ The change in the schooling question in 1992 did not significantly alter the measure of pre-college schooling, so this calculation can be made for the period form 1979 to 1998, or until the cohort is age 38. I assume the earnings of high school graduates are flat from age 39 to 65. Again, this conservative assumption weighs against finding a positive effect of the program.
} 


\section{Conclusion}

A key question in the debate over higher education policy is whether student aid increases college attendance or simply subsidizes college for infra-marginal youth. This paper has shown that aid eligibility can have a positive effect on college attendance: I find that a $\$ 1,000$ increase in the grant aid for which a person is eligible increases ultimate educational attainment by about 0.16 years and the probability of attending college by about four percentage points.

These results are roughly consistent with previous estimates of the effect of aid on education. This is somewhat surprising, since we suspect many of the cross-sectional estimates to be biased by correlation between aid and unobserved attributes that affect the probability of attending college. That the crosssectional estimates are consistent with the present results, as well as with the handful of other studies that control for unobserved heterogeneity, suggests that competing biases are at work in the cross-section. This is quite plausible: cross-sectional estimates of the effect of need-based aid are likely biased downward and estimates of the effect of merit aid are likely biased upward, since eligibility for these types of aid is correlated (negatively and positively, respectively) with the underlying propensity to attend college.

Analyses that pool these sources of aid may fortuitously arrive at an unbiased estimate of the causal effect of aid eligibility.

The paper has also shown that aid continues to pay dividends, in the form of ongoing educational investment, even after students stop receiving a subsidy. A student who has started college with the assistance of aid is more likely to continue schooling later in life than one that has never attempted college. This is consistent with the idea that there are initial, fixed costs of college entry which make the first year of college more expensive than additional years. An efficient policy would therefore be one that helps students cross the hurdle of college entry by offering relatively generous aid for the first year of college. While the new federal Hope Scholarship has this incentive structure, other federal aid programs do not. The Pell Grant program does not vary across years of college, and the Stafford loan is actually less generous in the first year, allowing freshmen to borrow just $\$ 2,625$ but juniors to borrow $\$ 5,500$. A 
relatively inexpensive way for government to increase the impact of the student aid programs would be to reverse these incentives, so that those considering college entry are offered the most generous subsidies. 


\section{References}

Aigner, Dennis (1973). "Regression With a Binary Independent Variable Subject to Errors of Observation." Journal of Econometrics 1:1, 49-59.

Angrist, Joshua (1993). "The Effect of Veterans Benefits on Education and Earnings." Industrial and Labor Relations Review 46:4, 637-52.

Angrist, Joshua and Guido Imbens (1995). "Two-Stage Least Squares Estimation of Average Causal Effects in Models with Variable Treatment Intensity." Journal of the American Statistical Association 90:430, 431-42.

Ashenfelter, Orley (1978). "Estimating the Effect of Training Programs on Earnings." Review of Economics and Statistics 6:1, 47-57.

Becker, Gary (1993). Human Capital. Chicago, IL: University of Chicago Press.

Bound, John and Sarah Turner (1999). "Going to War and Going to College: Did the GI Bill Increase Educational Attainment?’ Unpublished manuscript, University of Virginia.

Bureau of the Census (1974). Social and Economic Characteristics of Students: October 1972. Washington, DC: US Government Printing Office.

Card, David (1995). "Earnings, Schooling, and Ability Revisited." In Solomon W. Polachek, ed., Research in Labor Economics. Greenwich, CT: JAI Press.

College Board (various years). Trends in Student Aid. New York: College Board Publications.

Committee on Ways and Means (1979). Review of Social Security Student Benefit Program. Washington, DC: US Government Printing Office.

(1982). Implementation of 1981 Reconciliation Act Repeal of Social Security Student Benefit. Washington, DC: US Government Printing Office.

Congressional Budget Office (1977). Social Security Benefits for Students. Washington, DC: US Government Printing Office.

Freeman, Richard (1984). "Longitudinal Analyses of the Effects of Trade Unions." Journal of Labor Economics 2: 1-26.

Griliches, Zvi (1977). "Estimating the Returns to Schooling: Some Econometric Problems." Econometrica 45:1, 1-22.

Gruber, Jonathan (1994). "The Incidence of Mandated Maternity Benefits." American Economic Review $84: 3,622-41$. 
(1997). "The Incidence of Payroll Taxation: Evidence from Chile." Journal of Labor Economics 15:3, S72-S1101.

Hansen, W. Lee (1983). “The Impact of Student Financial Aid on Access.” In Joseph Froomkin, ed., The Crisis in Higher Education. New York: Academy of Political Science.

Hartman, Robert (1973). “The Rationale for Federal Support for Higher Education.” In Lewis Solmon and Paul Taubman, eds., Does College Matter? New York: Academic Press.

Huntley, Diane (1979). "Educational and Economic Characteristics of Student Beneficiaries: Black-White Differences." Social Security Bulletin (September): 3-10.

Kane, Thomas. (1994). "College Entry by Blacks since 1970: The Role of College Costs, Family Background, and the Returns to Education." Journal of Political Economy 102:5, 878-911.

(1995). "Rising Public College Tuition and College Entry: How Well Do Public Subsidies Promote Access to College?" National Bureau of Economic Research Working Paper 5164.

Leslie, Larry and Paul Brinkman (1988). The Economic Value of Higher Education. New York: Macmillan.

Lumsdaine, Robin, James Stock and David Wise (1996). "Why Are Retirement Rates So High at Age 65?" in David Wise, ed., Advances in the Economics of Aging. Chicago: University of Chicago Press.

Luzadis, Rebecca (1983). "The Effect of the Social Security Student Benefit Program on College-Going Decisions.” Unpublished manuscript, Cornell University.

Manski, Charles (1989). "Schooling as Experimentation: A Reappraisal of the Postsecondary Dropout Phenomenon." Economics of Education Review 8:4, 305-12.

Manski, Charles and David Wise (1983). College Choice in America. Cambridge, MA: Harvard University Press.

Meyer, Bruce (1995). "Natural and Quasi-Experiments in Economics." Journal of Business and Economic Statistics 13:2, 151-61.

Moulton, Brent (1986). "Random Group Effects and the Precision of Regression Estimates." Journal of Econometrics 32: 385-97.

National Center for Education Statistics (various years). Digest of Education Statistics. Washington, DC: US Government Printing Office.

Office of the Comptroller General (1979). "Social Security Student Benefits for Postsecondary Students Should be Discontinued." Washington, DC: US General Accounting Office. 
Reyes, Suzanne (1995). "Educational Opportunities and Outcomes: The Role of the Guaranteed Student Loan." Unpublished manuscript, Harvard University.

Social Security Administration (various years). Social Security Bulletin Annual Statistical Supplement. Washington, DC: Government Printing Office.

Springer, Philip (1976). "Characteristics of Student OASDI Beneficiaries: An Overview.” Social Security Bulletin (November): 3-32.

Stanley, Marcus (1999). “College Education and Mid-Century GI Bills.” Unpublished manuscript, Harvard University.

Summers, Lawrence H. (1989). "Some Simple Economics of Mandated Benefits." American Economic Review 79:2, 177-83. 
Table 1: Summary Statistics

\begin{tabular}{|c|c|c|c|c|c|}
\hline & \multicolumn{2}{|c|}{$\begin{array}{c}\text { High School Seniors } \\
1979-81 \\
\end{array}$} & \multicolumn{2}{|c|}{$\begin{array}{c}\text { High School Seniors } \\
1982-83 \\
\end{array}$} & \multirow{2}{*}{$\begin{array}{c}\text { Difference } \\
\text { in } \\
\text { Differences }\end{array}$} \\
\hline & $\begin{array}{l}\text { Father Not } \\
\text { Deceased }\end{array}$ & $\begin{array}{c}\text { Father } \\
\text { Deceased } \\
\end{array}$ & $\begin{array}{l}\text { Father Not } \\
\text { Deceased }\end{array}$ & $\begin{array}{c}\text { Father } \\
\text { Deceased }\end{array}$ & \\
\hline $\begin{array}{l}\text { Household Income When } \\
\text { High School Senior (1998\$) }\end{array}$ & $\begin{array}{c}50,782 \\
(26,470)\end{array}$ & $\begin{array}{c}33,439 \\
(21,411)\end{array}$ & $\begin{array}{c}48,221 \\
(24,319)\end{array}$ & $\begin{array}{c}34,634 \\
(22,433)\end{array}$ & $\begin{array}{l}-3,758 \\
(5,022)\end{array}$ \\
\hline $\begin{array}{l}\text { Age-Adjusted AFQT } \\
\text { Percentile }\end{array}$ & $\begin{array}{c}60.66 \\
(27.18)\end{array}$ & $\begin{array}{c}58.39 \\
(27.01)\end{array}$ & $\begin{array}{l}52.95 \\
(29.80)\end{array}$ & $\begin{array}{c}43.21 \\
(28.68)\end{array}$ & $\begin{array}{c}7.46 \\
(5.88)\end{array}$ \\
\hline Black & $\begin{array}{c}0.136 \\
(0.343)\end{array}$ & $\begin{array}{c}0.237 \\
(0.427)\end{array}$ & $\begin{array}{c}0.151 \\
(0.358)\end{array}$ & $\begin{array}{c}0.311 \\
(0.468)\end{array}$ & $\begin{array}{l}-0.059 \\
(0.073)\end{array}$ \\
\hline Hispanic & $\begin{array}{c}0.052 \\
(0.221)\end{array}$ & $\begin{array}{c}0.053 \\
(0.225)\end{array}$ & $\begin{array}{c}0.063 \\
(0.242)\end{array}$ & $\begin{array}{c}0.060 \\
(0.239)\end{array}$ & $\begin{array}{c}0.004 \\
(0.026)\end{array}$ \\
\hline Father Attended College & $\begin{array}{c}0.325 \\
(0.468)\end{array}$ & $\begin{array}{c}0.152 \\
(0.361)\end{array}$ & $\begin{array}{c}0.291 \\
(0.454)\end{array}$ & $\begin{array}{c}0.108 \\
(0.313)\end{array}$ & $\begin{array}{c}0.010 \\
(0.080)\end{array}$ \\
\hline Mother Attended College & $\begin{array}{c}0.232 \\
(0.422)\end{array}$ & $\begin{array}{c}0.114 \\
(0.320)\end{array}$ & $\begin{array}{c}0.199 \\
(0.399)\end{array}$ & $\begin{array}{c}0.177 \\
(0.386)\end{array}$ & $\begin{array}{l}-0.096 \\
(0.090)\end{array}$ \\
\hline $\begin{array}{l}\text { Single Parent Household } \\
\text { When HS Senior }\end{array}$ & $\begin{array}{c}0.154 \\
(0.361)\end{array}$ & $\begin{array}{c}0.784 \\
(0.430)\end{array}$ & $\begin{array}{c}0.190 \\
(0.393)\end{array}$ & $\begin{array}{c}0.804 \\
(0.401)\end{array}$ & $\begin{array}{l}-0.009 \\
(0.083)\end{array}$ \\
\hline Family Size & $\begin{array}{c}4.77 \\
(1.61)\end{array}$ & $\begin{array}{c}4.44 \\
(2.04)\end{array}$ & $\begin{array}{c}4.68 \\
(1.64)\end{array}$ & $\begin{array}{c}4.52 \\
(1.99)\end{array}$ & $\begin{array}{l}-0.17 \\
(0.33)\end{array}$ \\
\hline $\begin{array}{l}\text { Attended College Full-Time } \\
\text { by } 1996\end{array}$ & $\begin{array}{c}0.539 \\
(0.499)\end{array}$ & $\begin{array}{c}0.625 \\
(.0486)\end{array}$ & $\begin{array}{c}0.490 \\
(0.500)\end{array}$ & $\begin{array}{c}0.322 \\
(0.472)\end{array}$ & $\begin{array}{c}0.254 \\
(0.100)\end{array}$ \\
\hline $\begin{array}{l}\text { Highest Grade Completed by } \\
1996\end{array}$ & $\begin{array}{l}13.95 \\
(2.27)\end{array}$ & $\begin{array}{l}14.04 \\
(2.09)\end{array}$ & $\begin{array}{l}13.76 \\
(2.24)\end{array}$ & $\begin{array}{l}12.90 \\
(1.45)\end{array}$ & $\begin{array}{c}0.948 \\
(0.367)\end{array}$ \\
\hline Number of Observations & 2,451 & 107 & 938 & 49 & \\
\hline
\end{tabular}

Note: Means are of poverty and random samples, weighted by 1996 sample weights. Standard deviations are in parentheses in the first four columns. Standard errors are in parentheses in the difference-indifferences column. Standard errors adjusted for multiple observations within households. 
Table 2:

Difference in Differences

Probability of Attending College Full-Time by 1996

NLSY Random and Poverty Samples

$\mathrm{N}=3545$

\begin{tabular}{lccc}
\hline & Father Not Deceased & Father Deceased & Difference \\
\hline \hline High School Senior 1979-81 & 0.54 & 0.63 & 0.09 \\
High School Senior 1982-83 & 0.49 & 0.32 & -0.17 \\
Difference & 0.05 & 0.31 & 0.26 \\
\end{tabular}

Note: means are weighted by 1996 sample weights. 
Table 3: Difference-in-Differences

Probability of Attending College Full-Time by 1996

\begin{tabular}{|c|c|c|c|}
\hline & $\begin{array}{c}(1) \\
\text { Difference-in- } \\
\text { Differences }\end{array}$ & $\begin{array}{c}(2) \\
\text { Add covariates }\end{array}$ & $\begin{array}{l}\text { (3) } \\
\text { Add time-varying } \\
\text { covariates }\end{array}$ \\
\hline deceased father*senior 1979-81 & $\begin{array}{c}0.256 \\
(0.100)\end{array}$ & $\begin{array}{c}0.233 \\
(0.087)\end{array}$ & $\begin{array}{c}0.194 \\
(0.096)\end{array}$ \\
\hline deceased father & $\begin{array}{l}-0.169 \\
(0.082)\end{array}$ & $\begin{array}{l}-0.068 \\
(0.071)\end{array}$ & $\begin{array}{l}-0.044 \\
(0.078)\end{array}$ \\
\hline senior 1979-81 & $\begin{array}{c}0.048 \\
(0.022)\end{array}$ & $\begin{array}{c}0.021 \\
(0.029)\end{array}$ & $\begin{array}{l}-0.056 \\
(0.098)\end{array}$ \\
\hline family income/10,000 (\$1998) & & $\begin{array}{c}0.008 \\
(0.004)\end{array}$ & $\begin{array}{c}0.011 \\
(0.007)\end{array}$ \\
\hline AFQT score & & $\begin{array}{c}0.007 \\
(0.000)\end{array}$ & $\begin{array}{c}0.007 \\
(0.001)\end{array}$ \\
\hline Black & & $\begin{array}{c}0.302 \\
(0.022)\end{array}$ & $\begin{array}{c}0.270 \\
(0.040)\end{array}$ \\
\hline Hispanic & & $\begin{array}{c}0.175 \\
(0.024)\end{array}$ & $\begin{array}{c}0.167 \\
(0.041)\end{array}$ \\
\hline father attended college & & $\begin{array}{c}0.206 \\
(0.023)\end{array}$ & $\begin{array}{c}0.241 \\
(0.045)\end{array}$ \\
\hline mother attended college & & $\begin{array}{c}0.144 \\
(0.023)\end{array}$ & $\begin{array}{c}0.103 \\
(0.046)\end{array}$ \\
\hline single parent household & & $\begin{array}{l}-0.042 \\
(0.024)\end{array}$ & $\begin{array}{l}-0.094 \\
(0.041)\end{array}$ \\
\hline family size & & $\begin{array}{l}-0.013 \\
(0.005)\end{array}$ & $\begin{array}{l}-0.017 \\
(0.008)\end{array}$ \\
\hline family income $*$ senior $1979-81$ & & & $\begin{array}{l}-0.005 \\
(0.008)\end{array}$ \\
\hline AFQT * senior 1979-81 & & & $\begin{array}{c}0.001 \\
(0.001)\end{array}$ \\
\hline Black * senior 1979-81 & & & $\begin{array}{c}0.049 \\
(0.047)\end{array}$ \\
\hline Hispanic * senior 1979-81 & & & $\begin{array}{c}0.014 \\
(0.048)\end{array}$ \\
\hline father college * senior $1979-81$ & & & $\begin{array}{l}-0.048 \\
(0.053)\end{array}$ \\
\hline mother college $*$ senior $1979-81$ & & & $\begin{array}{c}0.059 \\
(0.052)\end{array}$ \\
\hline single parent $*$ senior $1979-81$ & & & $\begin{array}{c}0.078 \\
(0.051)\end{array}$ \\
\hline family size * senior $1979-81$ & & & $\begin{array}{c}.0005 \\
(0.010)\end{array}$ \\
\hline age dummies & & Y & $\mathrm{Y}$ \\
\hline $\mathrm{R}^{2}$ & 0.005 & 0.296 & 0.298 \\
\hline $\mathrm{N}$ & 3545 & 3477 & 3477 \\
\hline
\end{tabular}

Notes: Regressions weighted by 1996 sample weights. Dummies for missing income and parental education included in Columns (2) and (3) and interacted with "before" in Column (3). Family income is for a youth's high school senior year. Standard errors adjusted for heteroskedasticity and multiple observations within households. 
Table 4:

OLS and Probit Analysis

Probability of Attending College Full-Time by 1996

NLSY Random and Poverty Samples

\begin{tabular}{lccc}
\hline \hline & $(1)$ & $(2)$ & $(3)$ \\
& OLS & $\begin{array}{c}\text { Probit } \\
\text { Coefficient }\end{array}$ & $\begin{array}{c}\text { Probit } \\
\text { Marginal } \\
\text { Effect }\end{array}$ \\
\hline Difference-in-Differences & $\begin{array}{c}0.256 \\
(0.100)\end{array}$ & $\begin{array}{c}0.662 \\
(0.272)\end{array}$ & 0.256 \\
Add covariates & 0.233 & 0.808 & 0.258 \\
Add time-varying covariates & $(0.087)$ & $(0.309)$ & \\
& 0.194 & 0.705 & 0.248 \\
\hline \hline
\end{tabular}

Notes: In Column (1) and Column (2) are the coefficients on "deceased father*senior 1979-81" from, respectively, OLS and probit equations. The implied marginal effect from the probit equation is in Column (3). See Table 3 for full specifications of the regressions shown in the three rows. Standard errors adjusted for heteroskedasticity and multiple observations within households.

Table 5:

Difference-in-Differences

Highest Grade Completed by 1996

NLSY Random and Poverty Samples

$\mathrm{N}=3545$

Father Not Deceased Father Deceased Difference

High School Senior 1979-81

High School Senior 1982-83

Difference
13.95

13.76

0.19
14.04

12.90

$-0.86$

1.13

0.95

Note: means are weighted by 1996 sample weights. 
Table 6: Difference-in-Differences

Highest Grade Completed by 1996

\begin{tabular}{|c|c|c|c|}
\hline & $\begin{array}{c}(1) \\
\text { Difference-in- } \\
\text { Differences }\end{array}$ & $\begin{array}{c}(2) \\
\text { Add covariates }\end{array}$ & $\begin{array}{c}\text { (3) } \\
\text { Add time-varying } \\
\text { covariates }\end{array}$ \\
\hline deceased father*senior 1979-81 & 0.948 & 0.844 & 0.811 \\
\hline deceased father & -0.857 & -0.391 & -0.369 \\
\hline senior 1979-81 & $\begin{array}{c}(0.262) \\
0.191\end{array}$ & $\begin{array}{c}(0.280) \\
0.038\end{array}$ & $\begin{array}{l}(0.290) \\
-0.932\end{array}$ \\
\hline family income/10,000 (\$1998) & $(0.102)$ & $\begin{array}{c}(0.133) \\
0.037\end{array}$ & $\begin{array}{c}(0.388) \\
-0.021\end{array}$ \\
\hline AFQT score & & $\begin{array}{c}(0.018) \\
0.037\end{array}$ & $\begin{array}{c}(0.034) \\
0.034\end{array}$ \\
\hline Black & & $\begin{array}{c}(0.002) \\
0.993 \\
(0.086)\end{array}$ & $\begin{array}{c}(0.003) \\
0.685 \\
(0.153)\end{array}$ \\
\hline Hispanic & & $\begin{array}{c}0.514 \\
(0.100)\end{array}$ & $\begin{array}{c}0.438 \\
(0.170)\end{array}$ \\
\hline father attended college & & $\begin{array}{c}0.841 \\
(0.111)\end{array}$ & $\begin{array}{c}1.160 \\
(0.224)\end{array}$ \\
\hline mother attended college & & $\begin{array}{c}0.859 \\
(0.118)\end{array}$ & $\begin{array}{c}0.760 \\
(0.228)\end{array}$ \\
\hline single parent household & & $\begin{array}{l}-0.090 \\
(0.101)\end{array}$ & $\begin{array}{l}-0.216 \\
(0.180)\end{array}$ \\
\hline family size & & $\begin{array}{l}-0.060 \\
(0.021)\end{array}$ & $\begin{array}{l}-0.064 \\
(0.035)\end{array}$ \\
\hline family income $*$ senior $1979-81$ & & & $\begin{array}{c}0.079 \\
(0.039)\end{array}$ \\
\hline AFQT * senior 1979-81 & & & $\begin{array}{c}0.008 \\
(0.005)\end{array}$ \\
\hline Black * senior 1979-81 & & & $\begin{array}{c}0.468 \\
(0.181)\end{array}$ \\
\hline Hispanic * senior 1979-81 & & & $\begin{array}{c}0.124 \\
(0.208)\end{array}$ \\
\hline father college * senior 1979-81 & & & $\begin{array}{l}-0.428 \\
(0.250)\end{array}$ \\
\hline mother college $*$ senior $1979-81$ & & & $\begin{array}{c}0.149 \\
(0.260)\end{array}$ \\
\hline single parent $*$ senior $1979-81$ & & & $\begin{array}{c}0.173 \\
(0.211)\end{array}$ \\
\hline family size * senior $1979-81$ & & & $\begin{array}{c}0.001 \\
(0.042)\end{array}$ \\
\hline age dummies & & Y & $\mathrm{Y}$ \\
\hline $\mathrm{R}^{2}$ & 0.004 & 0.375 & 0.379 \\
\hline $\mathrm{N}$ & 3545 & 3477 & 3477 \\
\hline
\end{tabular}

Notes: See Table 2. 
Table 7: Alternative Treatment Group

Difference-in-Differences Estimates

NLSY Random and Poverty Samples

\begin{tabular}{|c|c|c|c|}
\hline & $\begin{array}{c}(1) \\
\text { Difference- } \\
\text { in- } \\
\text { Differences } \\
\end{array}$ & $\begin{array}{c}(2) \\
\text { Add } \\
\text { covariates }\end{array}$ & $\begin{array}{c}\text { (3) } \\
\text { Add time- } \\
\text { varying } \\
\text { covariates }\end{array}$ \\
\hline Treatment Group & \multicolumn{3}{|c|}{$\begin{array}{c}\text { Dependent Variable: } \\
\text { College Attendance by } 1996\end{array}$} \\
\hline father deceased & $\begin{array}{c}0.256 \\
(0.100)\end{array}$ & $\begin{array}{c}0.234 \\
(0.086)\end{array}$ & $\begin{array}{c}0.195 \\
(0.095)\end{array}$ \\
\hline father deceased or of retirement age & $\begin{array}{c}0.217 \\
(0.089)\end{array}$ & $\begin{array}{c}0.243 \\
(0.076)\end{array}$ & $\begin{array}{c}0.211 \\
(0.083)\end{array}$ \\
\hline Treatment Group & \multicolumn{3}{|c|}{$\begin{array}{l}\text { Dependent Variable: } \\
\text { Highest Grade Completed by } 1996\end{array}$} \\
\hline father deceased & $\begin{array}{c}0.948 \\
(0.367)\end{array}$ & $\begin{array}{c}0.852 \\
(0.355)\end{array}$ & $\begin{array}{c}0.817 \\
(0.375)\end{array}$ \\
\hline father deceased or of retirement age & $\begin{array}{c}0.936 \\
(0.370)\end{array}$ & $\begin{array}{c}1.050 \\
(0.335)\end{array}$ & $\begin{array}{c}1.025 \\
(0.349)\end{array}$ \\
\hline
\end{tabular}

Note: Standard errors adjusted for heteroskedasticity and multiple observations within households. The specifications of Columns (1) - (3) are as in Columns (1) - (3) of Table 3. The treatment group in the first row of each panel is limited to youth with a deceased father. The treatment group in the second row includes youth with a father who is either deceased or of retirement age. 


\section{Data Appendix: The National Longitudinal Survey of Youth}

The National Longitudinal Survey of Youth was initiated in 1979 with a sample of 12,686 youth aged 14 to 22. The Center for Human Resource Research (CHRR) drew a representative cross-section of 6,111 youth, along with over-samples of poor youth and military enlistees. I focus on the cross-section and poverty samples, which have been interviewed annually since 1979 . The 18 percent of respondents who had left the sample as of the 1996 survey are excluded from the analysis.

The Armed Forces Qualifications Test (AFQT) was administered to the NLSY sample in 1980. The respondents ranged in age from fourteen to twenty-two when they took this test. Since age has been shown to affect AFQT score, I regress AFQT on age dummies and use within-age percentile scores in the analysis. Parental education, as measured in the 1979 survey, is used to create a set of variables that indicate whether each parent completed any college. Variables indicating whether education is missing for either parent are also included in the analysis. I measure family income at the time a youth was a high school senior; all values are inflated to 1998 dollars. Family income is missing for about 20 percent of the sample. For such cases, family income is assigned the sample mean and a dummy is included in regressions to indicate that the value is imputed.

The key attendance variable of interest is whether a youth has attended college by 1996. I use the responses to an annual question about school enrollment to code whether a youth was observed attending college full-time during any of the surveys between his senior year of high school and 1996. The key completion variable is the highest grade completed by 1996 and is obtained from the 1996 survey. 
Figure 1

Number of Social Security College Student Beneficiaries

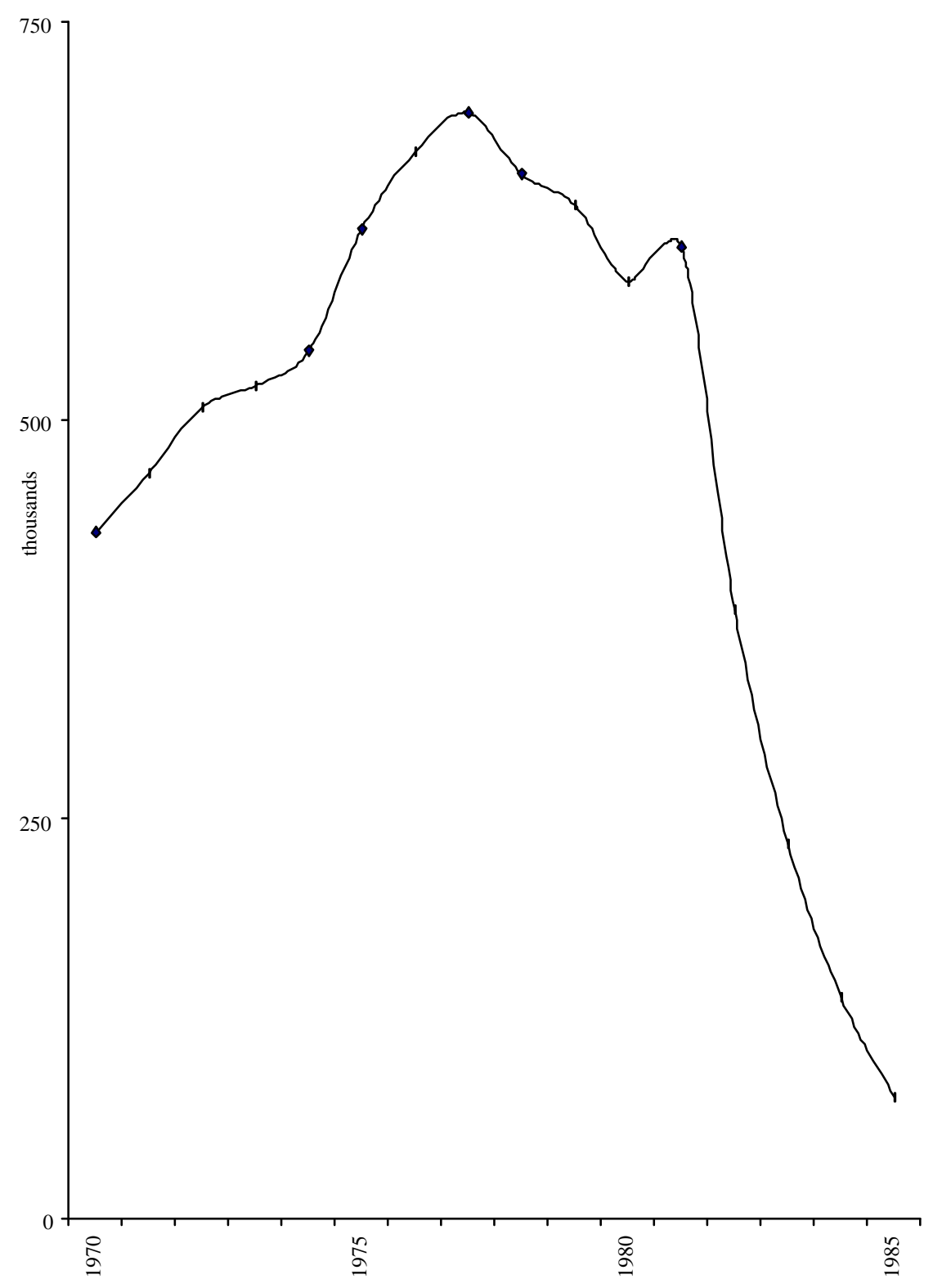

Source: Social Security Administration $(1985,1986)$. I have plotted $79 \%$ of the annual number of student beneficiaries. Yearly figures for the share in college are not available, but a 1973 SSA survey found that $79 \%$ of student beneficiaries were in post-secondary institutions. The moderate drop in the late Seventies is due to a national drop in enrollment rates and slowed growth in the college-age cohort (NCES (1998), Tables 6 and 15). 
Figure 2:

Benefits Paid to Social Security College Student Beneficiaries

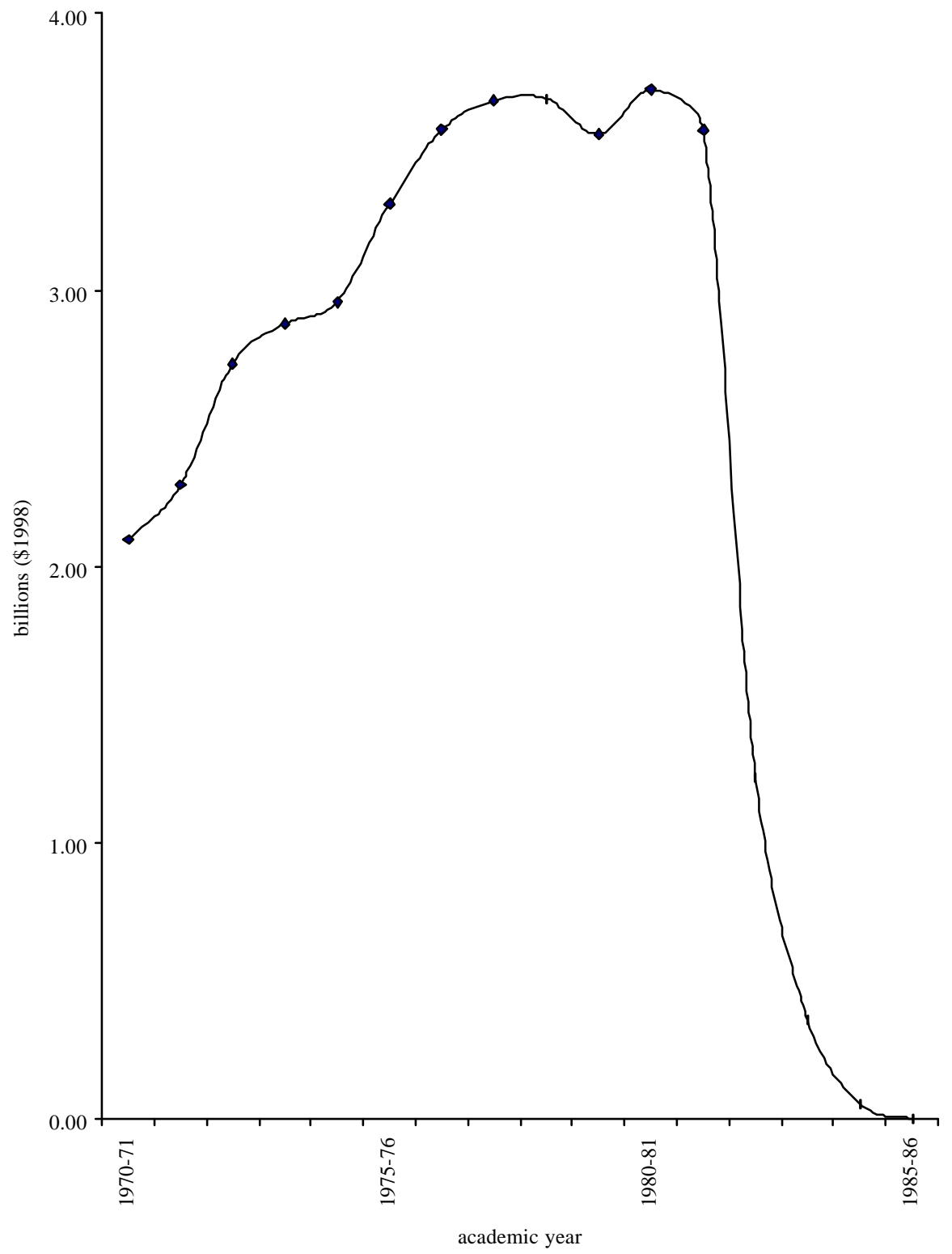

Billions of 1998 Dollars

Source: Table A in College Board (1998). 
Figure 3A

Highest Grade Completed by 1996

Control Group, Before and After

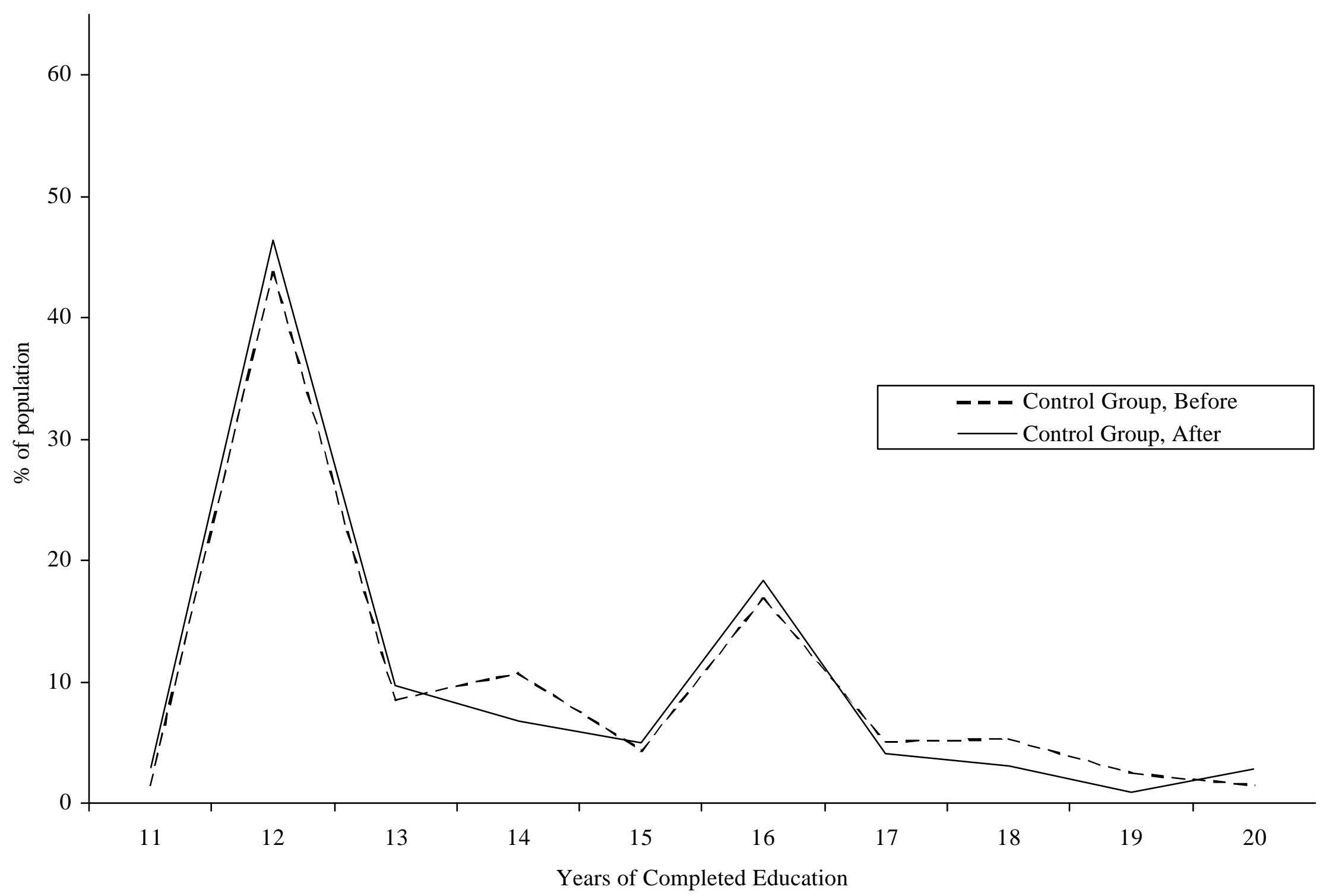


Figure 3B

Highest Grade Completed by 1996

Treatment Group, Before and After

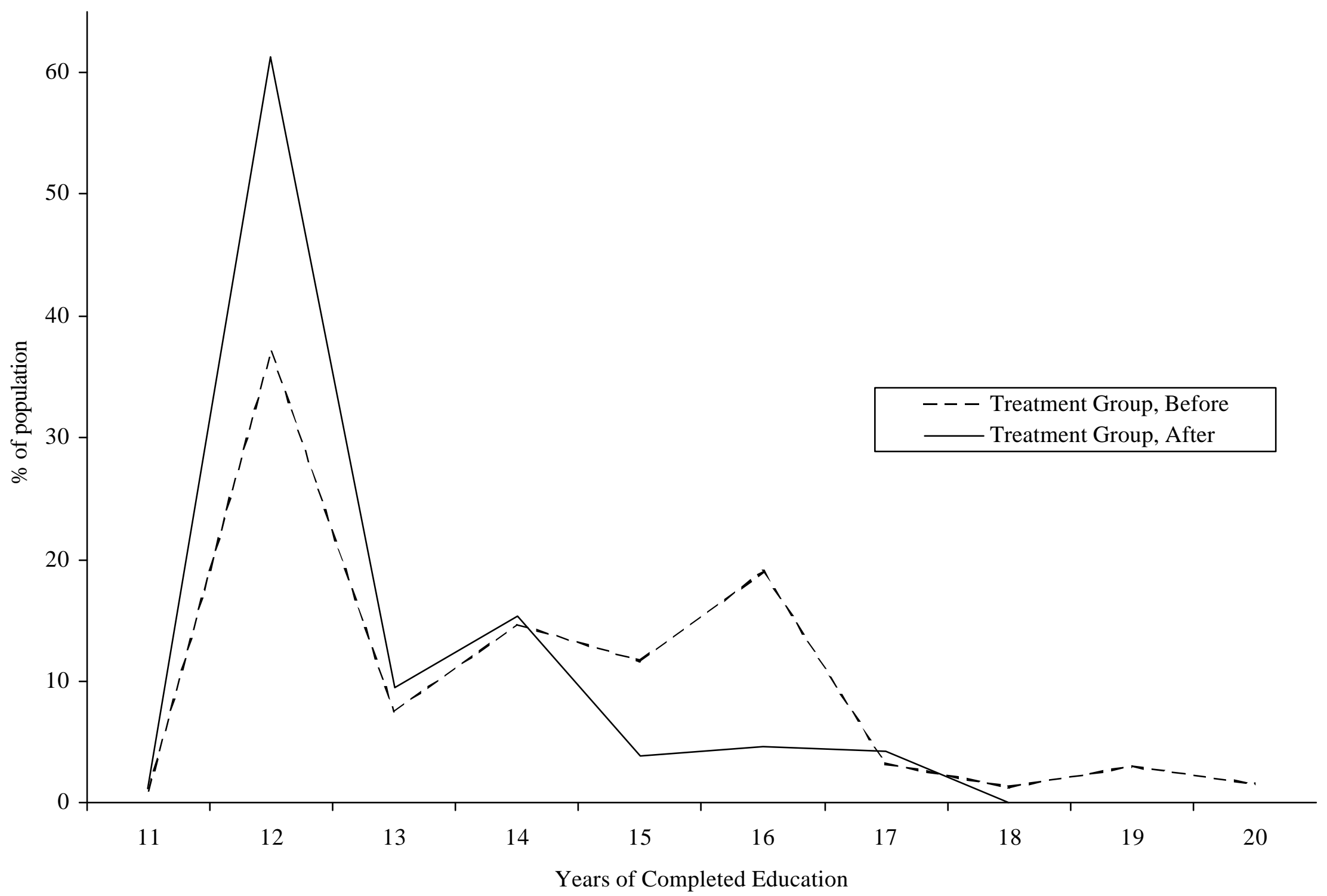


Figure 3C

Highest Grade Completed by 1996

Differences, Before vs. After

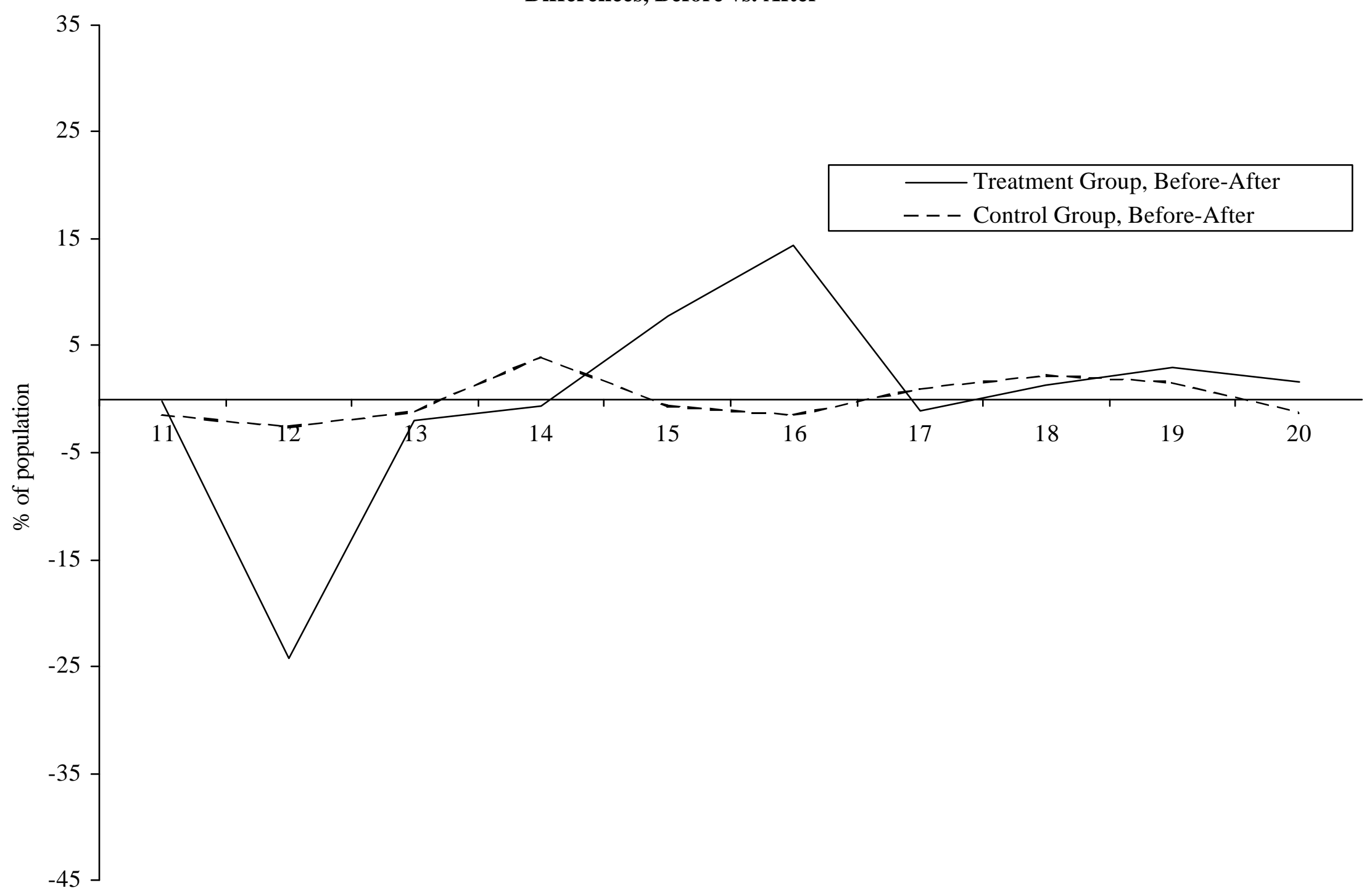

Years of Completed Education 
Figure 3D

Highest Grade Completed by 1996

Difference-in-Differences

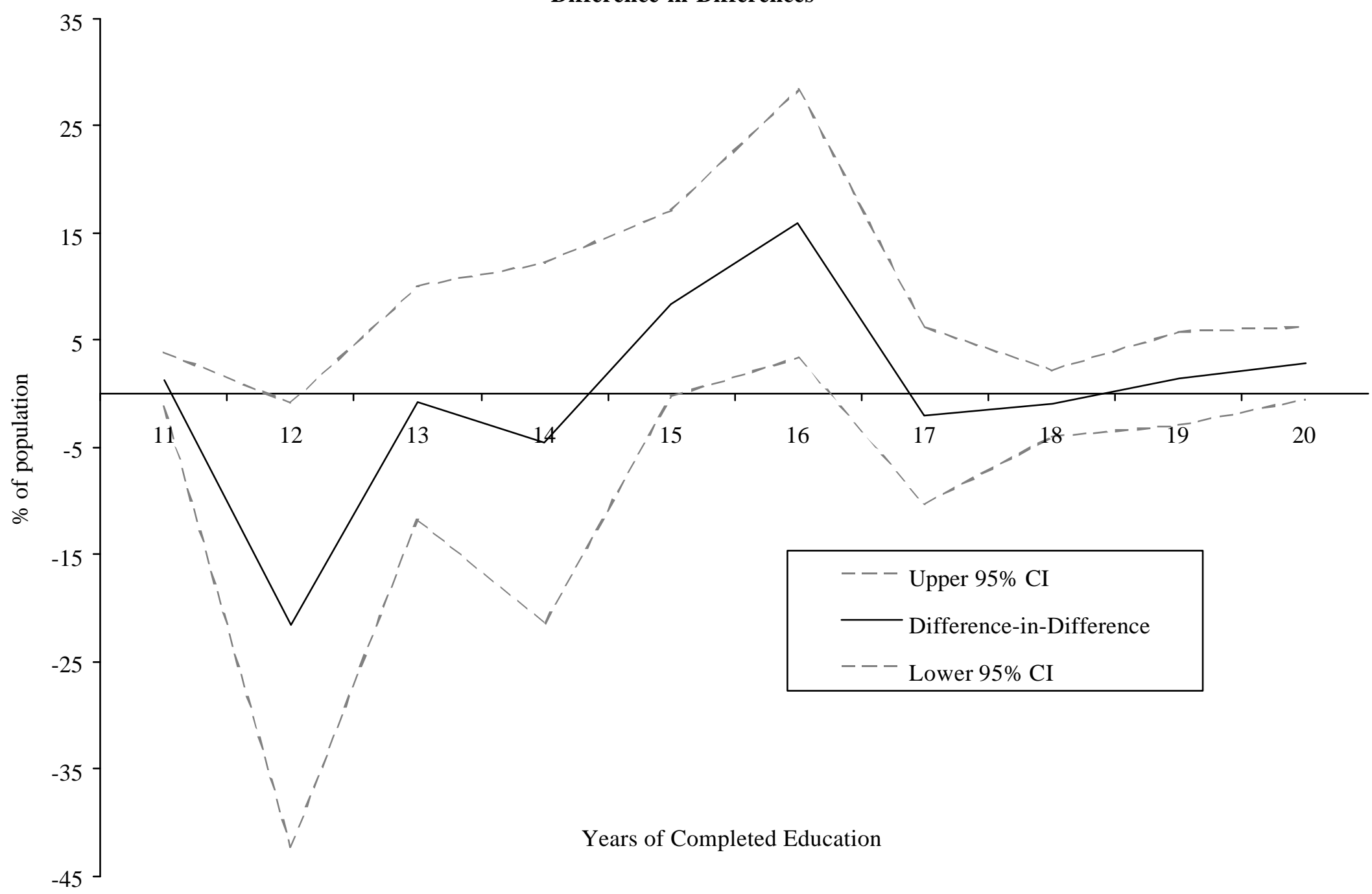


Figure 4A

Average Education, Age 18 to 31

Before Cohort

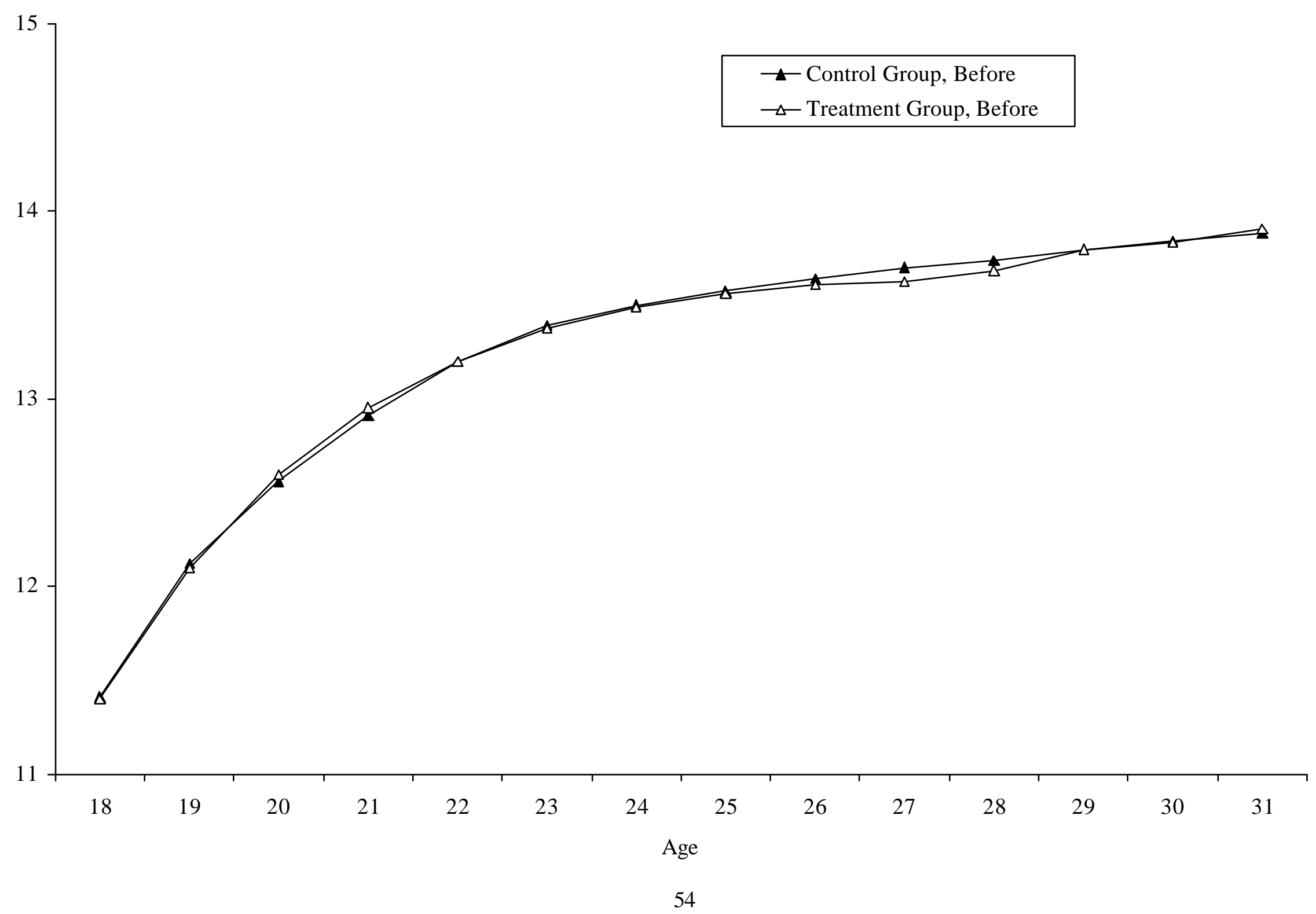


Figure 4B

Average Education, Age 18 to 31

After Cohort

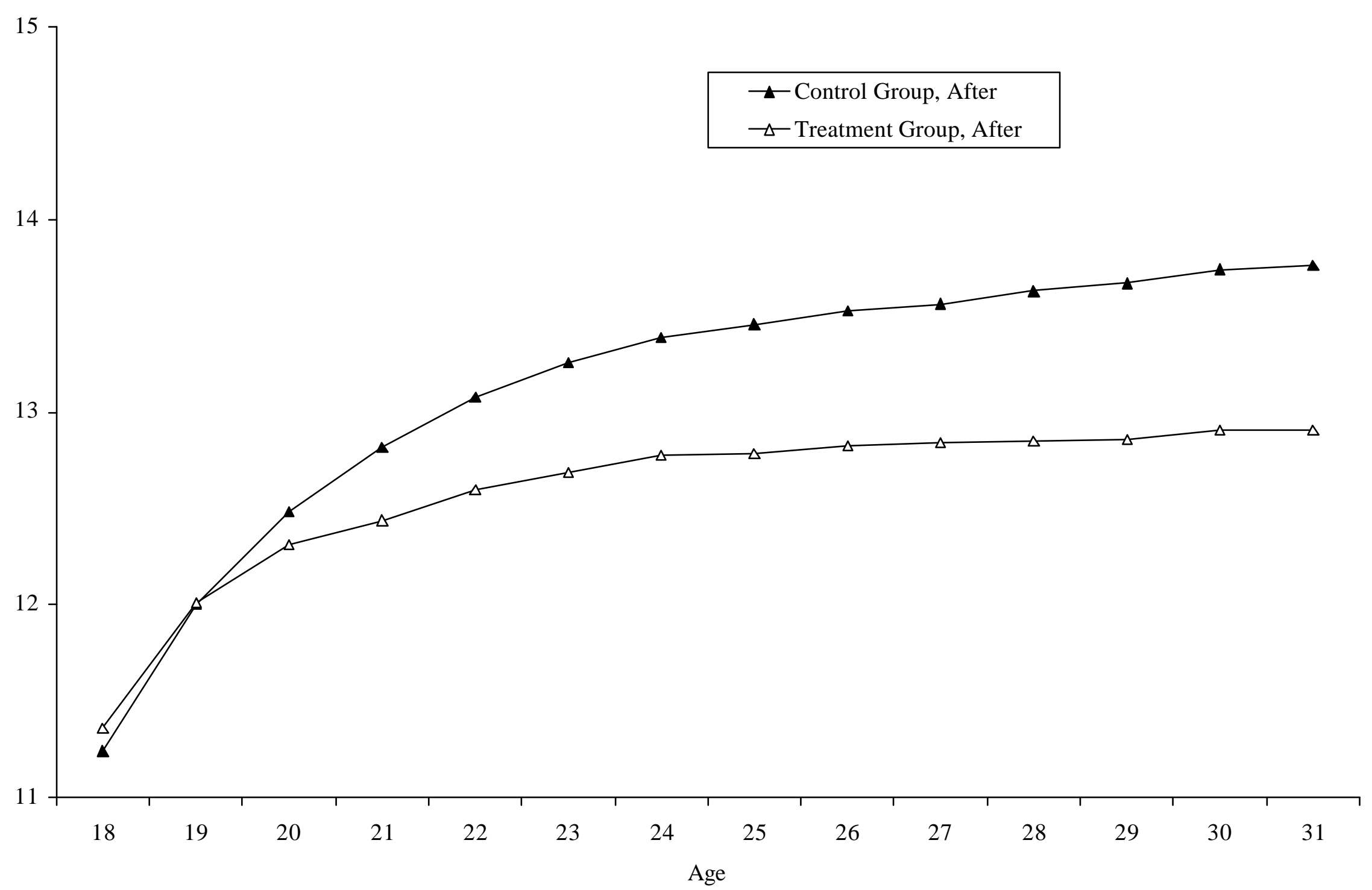


Figure 5

Highest Grade Completed by Age 23 and Age 31 Difference-in-Differences

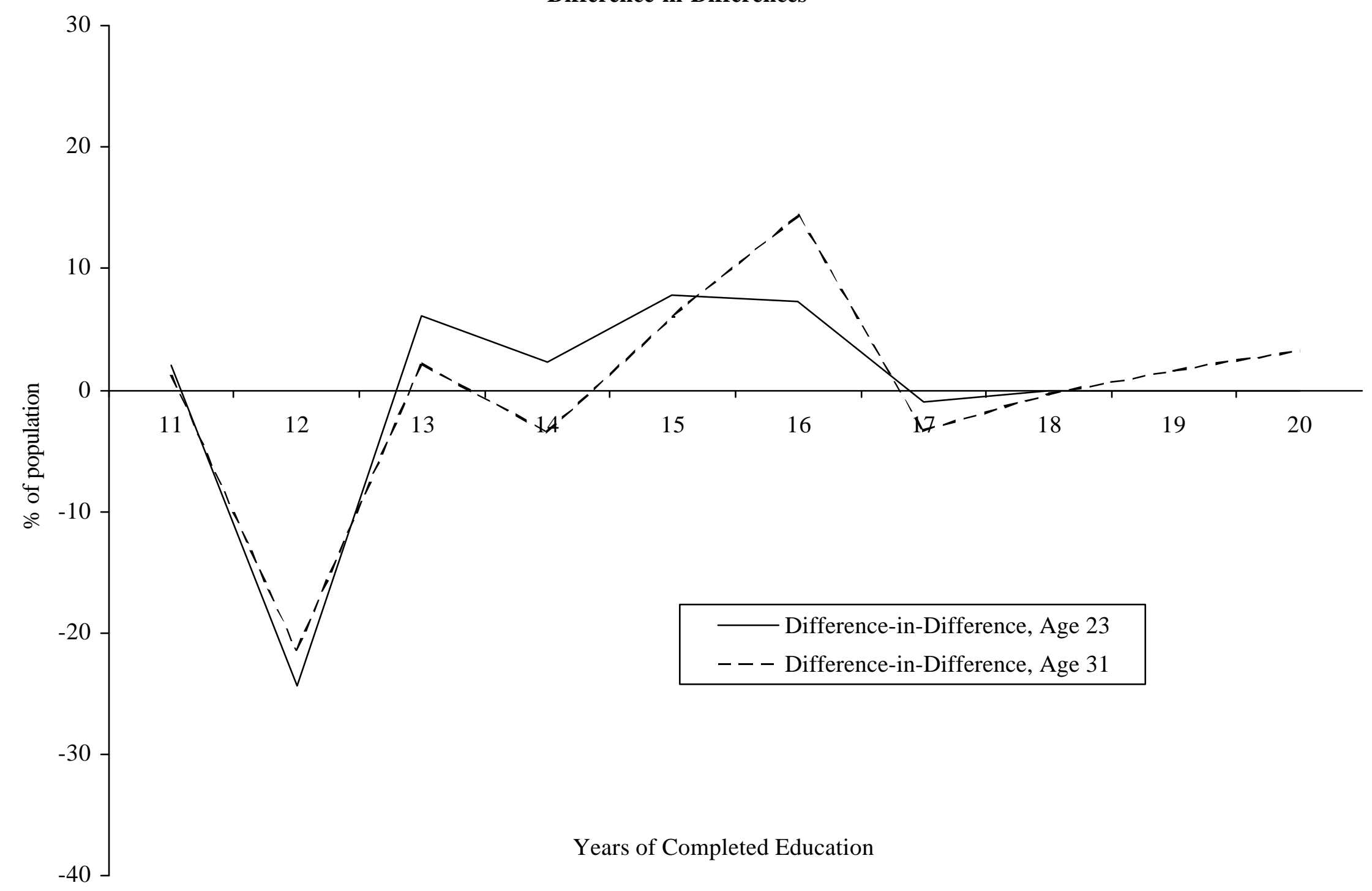




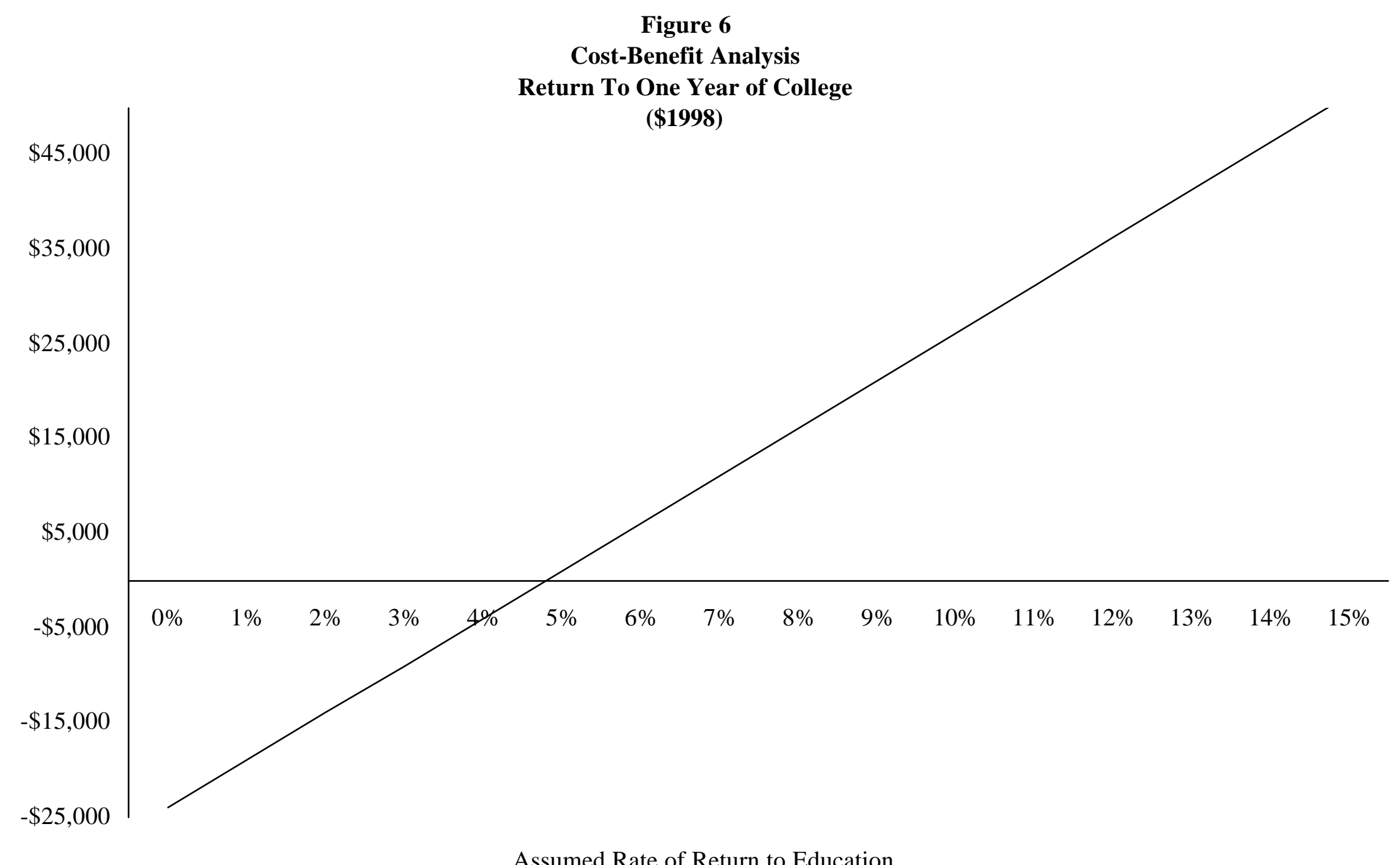

Note: Graphed is the PDV of the lifetime return to one year of college for the cohort aged 19 in 1979. Return is net of foregone earnings and aid needed to induce an additional year of college. See Section VIII for details of calculation. 